\title{
Stratigraphy of the Hawai'i Scientific Drilling Project core (HSDP2): Anatomy of a Hawaiian shield volcano
}

\author{
Michael O. Garcia and Eric H. Haskins \\ Department of Geology and Geophysics, University of Hawai i, 2525 Correa Road, Honolulu, Hawaii 96822, USA \\ (mogarcia@hawaii.edu)

\section{Edward M. Stolper and Michael Baker \\ Division of Geological and Planetary Sciences, California Institute of Technology, Pasadena, California 91125, USA}

[1] The Hawai'i Scientific Drilling Project (HSDP2) successfully drilled $\sim 3.1 \mathrm{~km}$ into the island of Hawai'i. Drilling started on Mauna Loa volcano, drilling $247 \mathrm{~m}$ of subaerial lavas before encountering $832 \mathrm{~m}$ of subaerial Mauna Kea lavas, followed by 2019 m of submarine Mauna Kea volcanic and sedimentary units. The $2.85 \mathrm{~km}$ stratigraphic record of Mauna Kea volcano spans back to $\sim 650 \mathrm{ka}$. Mauna Kea subaerial lavas have high average olivine contents $(13$ vol.\%) and low average vesicle abundances (10 vol.\%). Most subaerial Mauna Kea flows are ' $\mathrm{a}$ ' $\bar{a}(\sim 63 \%)$, whereas the Mauna Loa section contains nearly equal amounts of pāhoehoe and 'a'à (like its current surface). The submarine Mauna Kea section contains an upper, $\sim 900 \mathrm{~m}$ thick, hyaloclastite-rich section and a lower, $\sim 1100 \mathrm{~m}$ thick, pillow-lavadominated section. These results support a model that Hawaiian volcanoes are built on a pedestal of pillow lavas capped by rapidly quenched, fragmented lava debris. The HSDP2 section is compared here to a $1.7 \mathrm{~km}$ deep hole (SOH1) on Kilauea's lower east rift zone. Differences in the sections reflect the proximity to source vents and the lower magma supply to Kilauea's rift zone. Both drill core sections are cut by intrusions, but the higher abundance of intrusions in $\mathrm{SOH} 1$ reflects its location within a rift zone, causing more extensive alteration in the SOH1 core. The HSDP2 site recovered a relatively unaltered core well suited for geochemical analyses of the single deepest and most complete borehole ever drilled through a Hawaiian or any other oceanic island volcano.

Components: 21,448 words, 20 figures, 5 tables.

Keywords: stratigraphy; core logging; petrography; scientific drilling; basalt; Hawaii.

Index Terms: 8486 Volcanology: Field relationships (1090, 3690); 3615 Mineralogy and Petrology: Intra-plate processes (1033, 8415); 3625 Mineralogy and Petrology: Petrography, microstructures, and textures; 3641 Mineralogy and Petrology: Extrusive structures and rocks.

Received 6 June 2006; Revised 20 October 2006; Accepted 6 November 2006; Published 28 February 2007.

Garcia, M. O., E. H. Haskins, E. M. Stolper, and M. Baker (2007), Stratigraphy of the Hawai‘i Scientific Drilling Project core (HSDP2): Anatomy of a Hawaiian shield volcano, Geochem. Geophys. Geosyst., 8, Q02G20, doi:10.1029/2006GC001379.

Theme: Hawaii Scientific Drilling Project

Guest Editors: Don DePaolo, Ed Stolper, and Don Thomas 


\section{Introduction}

[2] Although Hawaiian shields are the most studied volcanoes on earth [e.g., Tilling and Dvorak, 1993], their interiors are poorly sampled and not well understood. This is a consequence of their rapid growth and subsidence [Lipman, 1995; Moore and Chadwick, 1995], as well as limited subaerial erosion and faulting, which expose only a relatively thin veneer of the volcano ( $<5 \%$ [e.g., Garcia et al., 1995]). The Hawai'i Scientific Drilling Project (HSDP) was designed to address this problem. The goal of this project was to penetrate the deep interior of a relatively young shield volcano, avoiding rift zones to minimize the effects of alteration [DePaolo et al., 2001]. Mauna Kea volcano (last eruption $\sim 4 \mathrm{ka}$ [Wolfe et al., 1997]) was selected as the target for this study (Figure 1). The project's feasibility was first evaluated on the basis of a "pilot hole" (HSDP1) drilled in 1993 along the coast of the island of Hawai' $i$ in the city of Hilo (Figure 1). The HSDP1 drilling achieved $\sim 90 \%$ core recovery with $\sim 280 \mathrm{~m}$ of Mauna Loa lavas and sediments overlying $\sim 776 \mathrm{~m}$ of Mauna Kea lavas [DePaolo et al., 1996]. The success of HSDP1 led to the drilling of HSDP2, which began 15 March 1999 at a site $\sim 2 \mathrm{~km}$ south of the HSDP1 drill site (Figure 1). When drilling operations halted on 23 September 1999, the final penetration depth was 3098 meters below sea level (mbsl), with $\sim 95 \%$ core recovery.

[3] This paper describes the downhole stratigraphy for the HSDP2 borehole, based on data compiled from on-site logging of the core, supplemented with examination of 265 thin sections. We provide the primary geological, volcanological, and petrographic context for many geochemical studies of the HSDP2 core. In addition, we compare the stratigraphy of the core with new stratigraphic and petrographic data for the Hawai'i Scientific Observation Hole 1 (SOH1) drilled into Kīlauea's east rift zone (KERZ). This comparison of two cored sequences of geochemically similar rocks allows us to evaluate the effects of distance from vent and emplacement conditions on the proportion of rock types (e.g., flows versus fragmental rocks) and their petrographic characteristics (e.g., vesicularity and phenocryst content). Finally, we present a model for the submarine growth of the flanks of Hawaiian volcanoes.

\section{Geologic Setting and Site Selection}

[4] The HSDP2 drill site is located in a disused rock quarry on industrial land adjacent to the Hilo
International Airport. The HSDP1 site was regarded as unsuitable for the lengthier site occupation required for the second phase of drilling. The HSDP2 site minimized environmental and community impacts and provided ready access to the services of the greater Hilo area. The site is also far from the summits and rift zones of adjacent volcanoes (e.g., $\sim 14 \mathrm{~km}$ south of the east rift zone of Mauna Kea, $28 \mathrm{~km}$ north of Kīlauea's east rift zone, and $45 \mathrm{~km}$ ESE of the summit of Mauna Kea; Figure 1). Thus the chances of encountering intrusions and hightemperature fluids were minimized, enhancing the likelihood of obtaining the freshest possible rocks for geochemical and paleomagnetic studies. The site was also selected to maximize the time interval sampled as a function of drilled depth (this was achieved by selecting a site distant from Mauna Kea's summit). A bonus from drilling at the chosen site was the recovery of a $\sim 247 \mathrm{~m}$ thick section of Mauna Loa flows.

\section{Methods}

\subsection{Hybrid Coring System}

[5] An important innovation of the HSDP2 was the construction and utilization of a hybrid coring system, which allowed seamless integration of wireline coring and rotary drilling capabilities. This system (owned by the Drilling, Observation and Sampling of the Earth's Continental Crust Corporation, DOSECC) is a top-driven, wireline coring system that attaches to a host rotary rig for continuous coring to depths of $\sim 6000 \mathrm{~m}$. During coring operations, standard wireline coring rods were used with a cylindrical, thin kerf diamond bit that drilled a $\sim 10 \mathrm{~cm}$ hole and recovered core with a diameter of $\sim 6.4 \mathrm{~cm}$. The core barrel was retrieved by a wireline winch, allowing the rods and coring assembly to remain at the bottom of the hole. When drilling operations required removing pipe, widening the hole, setting casing, or cementing, the hybrid the coring system was set aside allowing use of the rig's rotary capabilities.

\subsection{Drilling}

[6] The HSDP2 ended at a depth of 3098 meters below sea level (mbsl), exceeding its depth objective $(2440 \mathrm{mbsl})$ by more than $25 \%$ [DePaolo et al., 2001]. The average coring penetration rate in the subaerial section $(1.8 \mathrm{~m}$ above sea level to $1079 \mathrm{mbsl}$ ) was $>48 \mathrm{~m} /$ day, $60 \%$ faster than for HSDP1. The higher coring rate was probably a result of using the hybrid coring system for HSDP2 


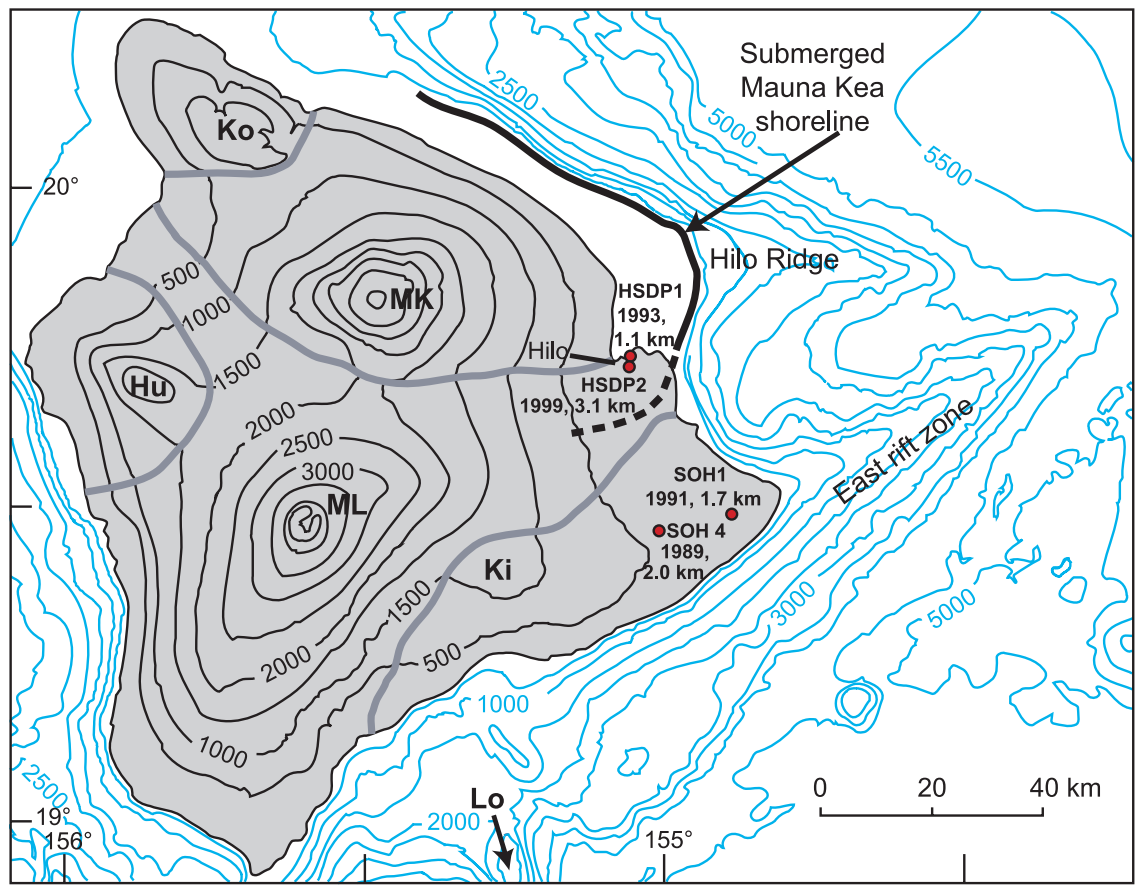

Figure 1. Topographic and bathymetric map of the island of Hawai $i$, with elevations and depths in meters. The five volcanoes that make up the island (Ko, Kohala; MK, Mauna Kea; Hu, Hualālai; ML, Mauna Loa; Ki, Kīlauea) are separated by gray lines; a black arrow points to the offshore Loihi seamount (Lo). The sites where drill cores discussed in this paper were collected (HSDP2, HSDP1, SOH1, and SOH4) are marked by red dots and labeled according to the year drilling was completed and total depth. The end of shield-stage Mauna Kea shoreline is defined by a marked break in slope [Wolfe et al., 1997] and is shown offshore by a heavy black curve. The dashed line shows the extrapolated shoreline beneath the younger Mauna Loa surface lavas near the HSDP sites.

drilling. The coring penetration rates $(\sim 25 \mathrm{~m} /$ day $)$, bit longevity, and core recovery were slower in the upper part of the submarine section due to the poorly consolidated character of the volcaniclastic sediments that dominate this part of the submarine section (Figure 2). The low penetration rates and poor recovery in the upper submarine section led to the decision to drill with a tricone rotary bit through two intervals of this poorly consolidated material (i.e., $1140-1223 \mathrm{mbsl}$ and $1243-1260 \mathrm{mbsl}$; Figure 3). No core or cuttings were recovered in these two intervals. Core recovery and bit life improved in the more consolidated hyaloclastitedominated section ( $>1500 \mathrm{mbsl})$ to an average of $\sim 25 \mathrm{~m}$ /day until the first occurrence of pillow lavas at 1984 mbsl (Figure 3). The highly fractured nature of most of these pillow lavas, along with the increasing times required for core recovery and bit replacement at progressively greater depths, reduced the average penetration rate to $\sim 20 \mathrm{~m}$ /day below 1984 mbsl. At several depth intervals, the borehole was widened and straightened using a tricone rotary bit, and casing strings of decreasing diameter were inserted for hole preservation (Figure 2). The lower section of the borehole was cased to $2998 \mathrm{mbsl}$ in 2003.

[7] An unexpected result of the HSDP2 drilling was the discovery of significant artesian groundwater. The shallowest artesian flow was from a fresh water aquifer at 100-600 mbsl (in the region of the Mauna Loa to Mauna Kea transition), which produced $\sim 7300 \mathrm{~L} / \mathrm{min}$. This aquifer may indicate that there are additional sources of fresh, artesian groundwater elsewhere in Hawai' $i$ near the interfaces between volcanoes. Artesian saltwater aquifers were discovered below 2000 mbsl within the sequence dominated by pillow lavas. These aquifers strongly influence temperatures in the drill hole. Temperatures in the shallow portion of the HSDP2 hole decrease with depth to $\sim 8^{\circ} \mathrm{C}$ near 600 mbsl (Figure 2). A similar decrease in HSDP1 was related to seawater infiltration [Thomas et al., 1996]. In the shallow submarine HSDP2 section, temperatures are nearly isothermal (Figure 2), probably due to seawater circulation through the highly permeable, poorly consolidated hyaloclastite units. Below $\sim 1800 \mathrm{~m}$, the temperature gradient is $\sim 20^{\circ} \mathrm{C} / \mathrm{km}$ with a maximum temperature of $45^{\circ} \mathrm{C}$ 


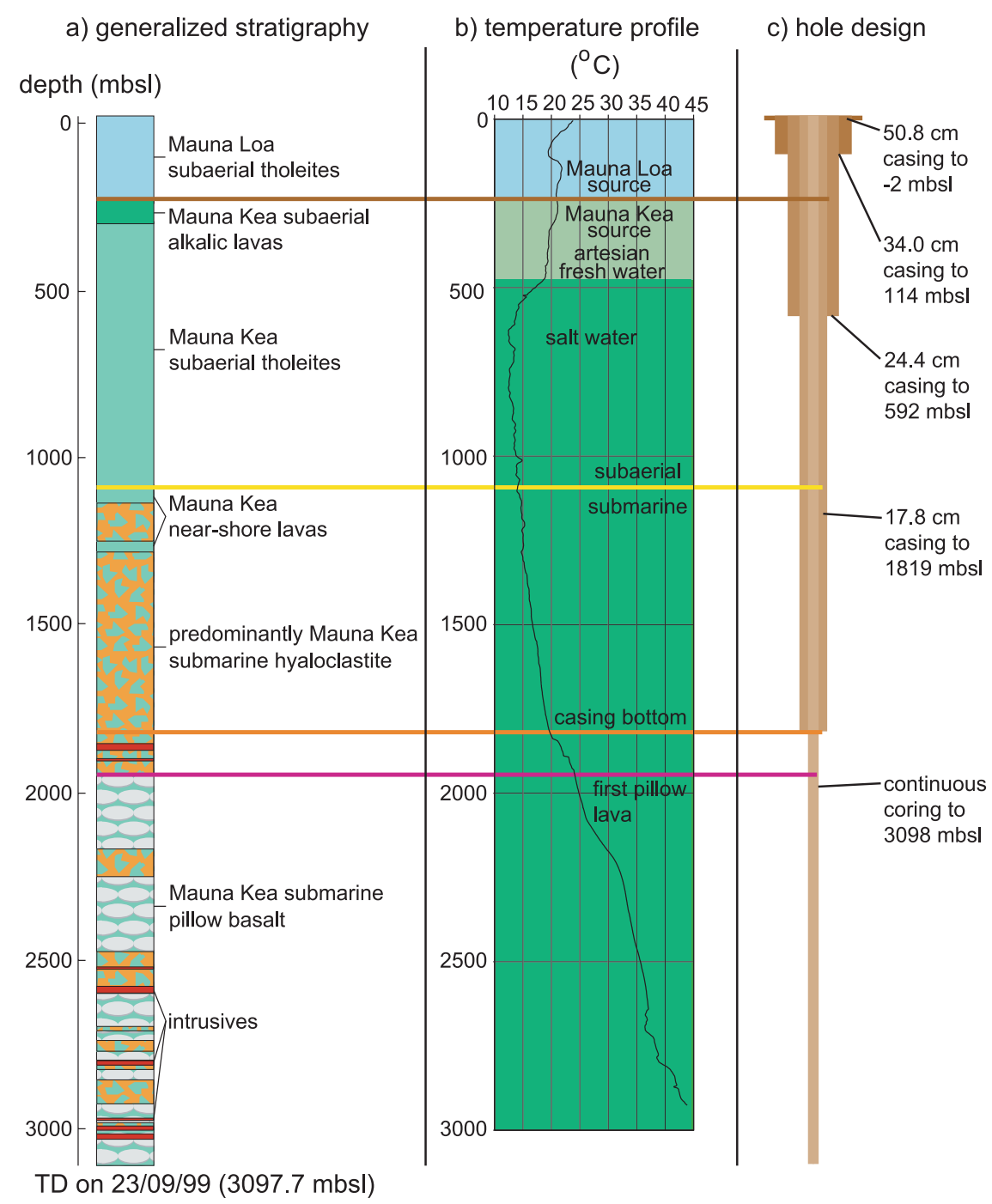

Figure 2. Downhole summary of the HSDP2: (a) generalized stratigraphy with major rock units, (b) temperature profile with areas of water intrusion, and (c) hole design with casing sizes and depths. Modified after DePaolo et al. [2001].

at the bottom of the hole (Figure 2). These results indicate that site selection successfully avoided high-temperature, hydrothermal conditions.

\subsection{Summary of Core Handling Procedures}

[8] HSDP2 core drilling was conducted 24 hours a day. Rock core was removed from the core barrel by the drilling crew and placed in sequentially numbered, $\sim 1.8 \mathrm{~m}$ long, oriented PVC half cylinders (with a series of $\sim 5 \mathrm{~mm}$ diameter water drainage holes). After being filled with core, these cylinders were fitted with foam end blocks and PVC top covers for transport across the drill site to the processing area. Handling of the core, including washing, marking, boxing, longitudinal slabbing (to create a 1/3 archive and 2/3 working split of the core), drying, scanning, and box photography were all done within a few days of recovery according to procedures developed for this project [Hawaii Scientific Drilling Project, 2000].

[9] Core logging was done only on the working split. Several steps were taken to ensure the quality and consistency of the logging. First, all data were entered directly into the Drilling Information System computer database (maintained by the International Continental Drilling Project at Potsdam, Germany) using standardized logging forms. The log report for each box of core consists of three parts: an annotated digital photograph of the box, a description of the core prepared using the standardized logging forms, and point count information on rock mineralogy and vesicularity. Core logging was 


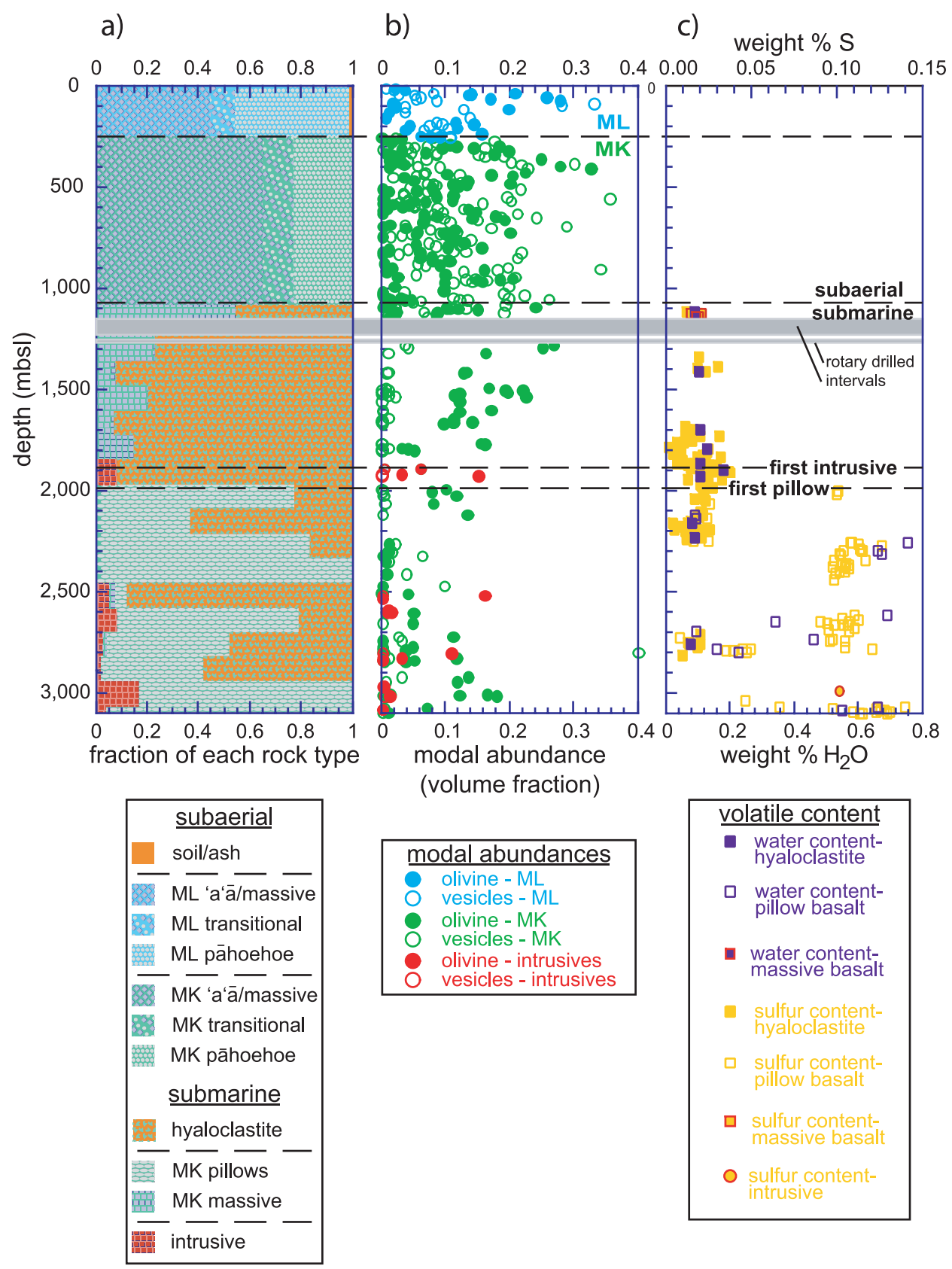

Figure 3. Summary of core logging observations and volatile glass data from the HSDP2 core hole: (a) relative proportions of rock types versus depth in 250 m increments; (b) abundances of phenocrysts and vesicles versus depth; and (c) water (purple symbols) and S contents (yellow symbols) of HSDP2 glasses versus depth; volatile contents are bimodal, with the lower values indicative of degassing under subaerial conditions and the higher values indicative of submarine eruption [Seaman et al., 2004]. Note the gaps of 17 and $83 \mathrm{~m}$ near the top of the submarine section from tricone rotary drilling in poorly consolidated hyaloclastite. These are the only sections of the hole that were not continuously cored. Modified after DePaolo et al. [2001].

done by the core logging staff supplemented by short-term volunteers. To maintain consistency and accuracy, their work was reviewed and edited first by M. Garcia and later by E. Stolper. These logs and additional news concerning the drilling project are available online at http://www. icdp-online.de/ contenido/icdp/front_content.php?idcat $=714$. The core is currently stored, and available for inspection and sampling at the American Museum of Natural History in New York City.

[10] The core was divided into units on the basis of observed contacts and/or variations in features such 


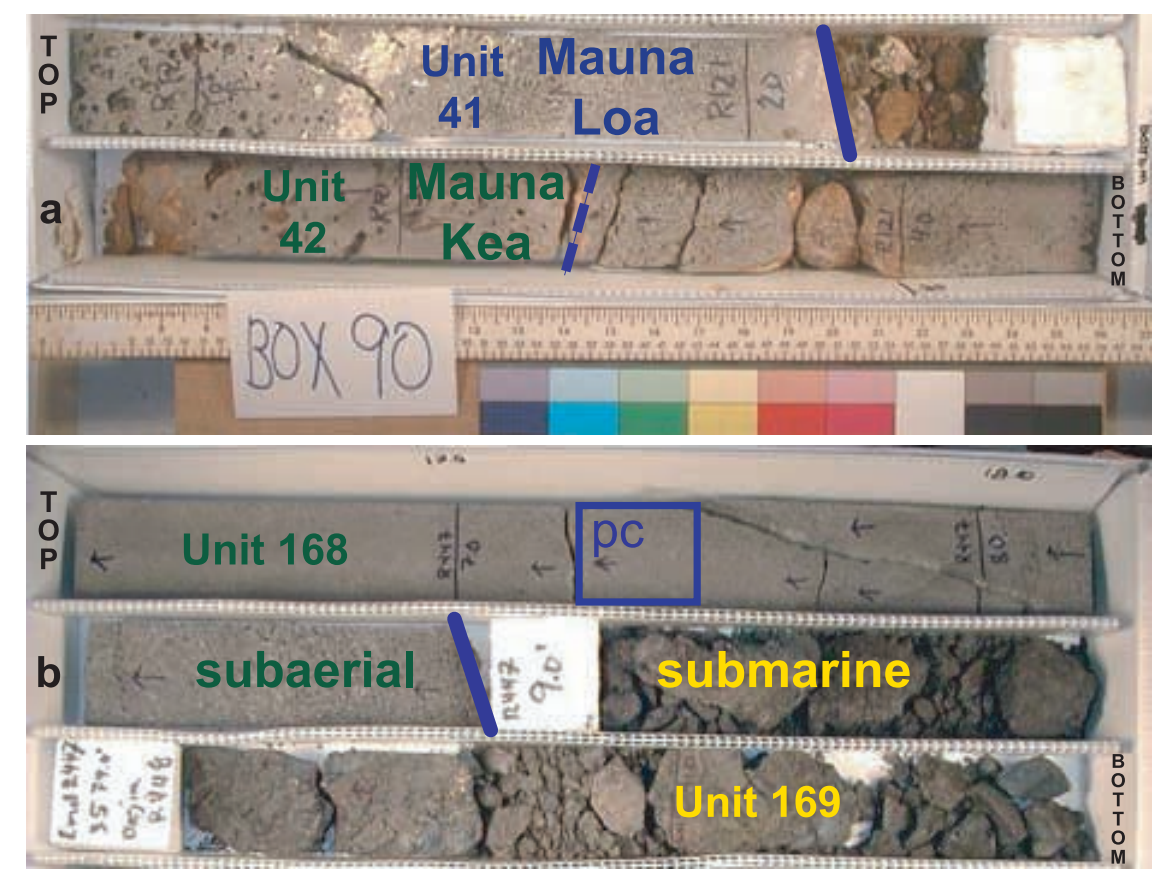

Figure 4. Photos of parts of two working boxes showing major stratigraphic contacts. (a) Mauna Loa/Mauna Kea; contact shown by solid blue line (Box 90). (b) Mauna Kea subaerial/submarine contact (Box 384). The boxes are organized with top at upper left and bottom at lower right, like this page. The solid blue lines denote the unit contacts; the dashed blue line in the upper photo indicates an internal unit boundary. The blue box with a "pc" label shows the location of a point count. The scale bar is in inches and centimeters, and it applies to both boxes, which are approximately $61 \mathrm{~cm}$ long. The color chart gives the true colors.

as mineralogy, structure, lithology, etc. A conservative approach was taken in delineating new units. Thus sequences of lithologically similar flows not clearly separated by distinct contacts were combined into single units. These sequences of flows are similar to the many overlapping flows being deposited by the current eruption of Killauea [e.g., Hon et al., 1994]. However, internal unit boundaries (e.g., lobes of a pāhoehoe flow, glassy pillow margins, and the presence of inter-pillow breccia) were recorded. Logging information was recorded for each unit in every core box $(\sim 3 \mathrm{~m}$ of core), including identification of contacts and their type (e.g., intrusive or depositional), groundmass textures, the presence or absence of volcanic glass, vesicle abundance, extent of alteration and fracturing, any sedimentary features, and general comments. The abundances (in volume \%) of phenocrysts (i.e., crystals $>1 \mathrm{~mm}$ ), groundmass, and vesicles were determined for each rock unit in each core box where possible on the basis of two 100 -point counts on representative portions of the core. For the hyaloclastites, selected large clasts were pointed counted. The point counts were done under a binocular microscope (or with a $10 \times$ hand lens) using a $16 \mathrm{~cm}^{2}$ transparent sheet printed with
100 grid intersections. Modal classification of the volcanic rocks was based on their vesicle-free normalized phenocryst abundances using the following ranges: aphyric $(<1 \%)$, sparsely porphyritic $(1-2 \%)$, moderately porphyritic $(2-10 \%)$, highly porphyritic $(>10 \%)$. Contacts, internal boundaries, point count locations and other notable features were labeled on digital box photographs (Figure 4). Rock names for flows, pillows, and intrusives were based both on the normalized (vesicle-free) abundance and identity of phenocrysts. For example, a basalt with $2-10 \%$ total phenocryst content with both olivine and plagioclase phenocrysts (but olivine >plagioclase) would have been called a "moderately plagioclase-olivine-phyric basalt," following the format of Streckeisen [1973]. A more detailed description of logging and point counting procedures is given by Hawaii Scientific Drilling Project [2000].

[11] Glassy, fragmental materials in the submarine section of the HSDP2 core were classified as "hyaloclastites," although these deposits were formed by a variety of mechanisms (K. P. Bridges et al., Submarine growth of a Hawaiian shield volcano based on volcaniclastics in the Hawaii Scientific Drilling Project 2 core, submitted to 
Geochemistry, Geophysics, Geosystems, 2007; hereinafter referred to as Bridges et al., submitted manuscript, 2007). For each unit, sedimentary features (e.g., cross bedding, grading, grain size, sorting, rounding) and clast lithology were noted using the classification scheme of Compton [1962]. Contacts between hyaloclastite units were delineated on the basis of changes in clast lithology. For example, a new unit was designated if the hyaloclastite changed from monomict (only one clast lithology) to polymictic (multiple clast lithologies) or if there was a significant change in the dominant clast lithology of a polymictic unit. Finer-grained, well-sorted sections (sandstones) were designated as new lithologic units only if they separated two distinct hyaloclastite units. When a lava interval within a hyaloclastite sequence was thicker than $61 \mathrm{~cm}$ (the length of a single row of a working core box) and its origin was ambiguous (e.g., a large clast, a flow, or an intrusive), it was defined as a separate unit. For each box, the maximum clast size and the average of the ten largest clasts were recorded along with whether the clasts are matrix or clast supported. Each clast lithology was given a rock name that included a description of vesicularity (sparse $<5 \%$, moderate $5-15 \%$, abundant $15-$ $30 \%$, very abundant $>30 \%$, and variable) and mineralogy (e.g., a "sparsely vesicular, moderately olivine-phyric basalt") based on two 100-point modes. However, if a hyaloclastite was polymictic yet was composed mostly of one clast type, it was given a modified name such as "basaltic hyaloclastite (polymictic, dominantly highly olivinephyric basalt clasts)". The following observations were also made for each clast lithology: (1) relative abundance (sparse $<5 \%$, common $5-20 \%$, or abundant $>20 \%$ ); (2) common clast size (small, $1-5 \mathrm{~cm}$; medium, 5-10 cm; large, $10-15 \mathrm{~cm}$; or very large, $>15 \mathrm{~cm})$; (3) size range $(\mathrm{cm})$; and (4) rounding (subangular, angular, subrounded or rounded). General comments such as vesicle size and shape, phenocryst size and shape, and the presence of secondary minerals were also noted.

\section{HSDP2 Stratigraphy}

[12] A total of 345 lithologic units were identified in the HSDP2 drill core (Table 1). These units were grouped into four depth zones; subaerial Mauna Loa (surface to $246 \mathrm{mbsl}$ ), subaerial Mauna Kea (246-1079 mbsl), shallow submarine Mauna Kea (1079-1984 mbsl), and deep submarine Mauna Kea (1984-3098 mbsl). Nearly all of the subaerial section (99.0\% of the Mauna Loa section; $99.8 \%$ of the Mauna Kea section) consists of lava (151 units); the remainder includes 12 thin ash layers, three soils, and one sand deposit spanning a total depth of $3.9 \mathrm{~m}$ (Table 1). In contrast, the $2.2 \mathrm{~km}$ thick submarine section is dominated by sediments $(55.6 \%)$, most of which $(98.3 \%)$ are classified here as hyaloclastite. Lava comprises $41.7 \%$ of the submarine section, with massive units (see below) mostly in the shallow portion $(<1984 \mathrm{mbsl})$ and pillows observed only below this depth. Intrusions invade only the submarine section, representing $\sim 1.5 \%$ of the total section. The submarine section has been subdivided here into an upper sequence (1079-1984 mbsl), with abundant hyaloclastite $(\sim 82 \%)$ and no pillow lavas (Table 1$)$, and a lower sequence dominated by pillow lavas $(\sim 61 \%$ below 1984 mbsl; Table 1, Figure 2). An $\sim 8 \mathrm{~m}$ thick sandstone, the thickest epiclastic unit in the HSDP2 section, separates these two sequences (see auxiliary material $^{1}$ Table S1, a complete listing of all units). This thick sediment may record a volcanic hiatus. These four zones are discussed in detail in the next section.

\subsection{Mauna Loa Section (Surface to 246 mbsl)}

[13] Drilling started on the $\sim 1.34$ ka Pana'ewa lava flow [Moore et al., 1996]. Whole-rock major, trace element, and isotopic analyses indicate that all of the flows from the surface to a depth of 246 mbsl (i.e., to the base of unit 41) are from Mauna Loa [e.g., Blichert-Toft et al., 2003; Rhodes and Vollinger, 2004]. The Mauna Loa section consists of 100 subaerial lava flows divided into 32 units with six ash units, two soils, and a sandstone (Table 1; Table S1). These rocks and sediments are thought to have been deposited over a period of $\sim 100 \mathrm{ka}$ [Sharp and Renne, 2005]. The average Mauna Loa flow unit resurfacing interval at the HSDP2 site is thus $\sim 3 \mathrm{ka}$. This estimate is consistent with those based on the HSDP1 section and from the upper slopes of Mauna Loa (3-5 ka [Beeson et al., 1996]). The $\sim 3$ ka between successive units at the HSDP2 site was apparently insufficient to develop significant soils (i.e., recoverable by drilling) on the Mauna Loa lava flows except where ash was present (two of the six ashes in the section have significant overlying soils, $>10 \mathrm{~cm}$ thick; units 33 and 38). However, this interval was long enough and the environment was wet enough (rainfall in Hilo averages $~ 330 \mathrm{~cm} / \mathrm{yr}$; http://www.

${ }^{1}$ Auxiliary materials are available at $\mathrm{ftp}: / / \mathrm{ftp}$. agu.org/apend/gb/ $2006 \mathrm{gc} 001379$ 


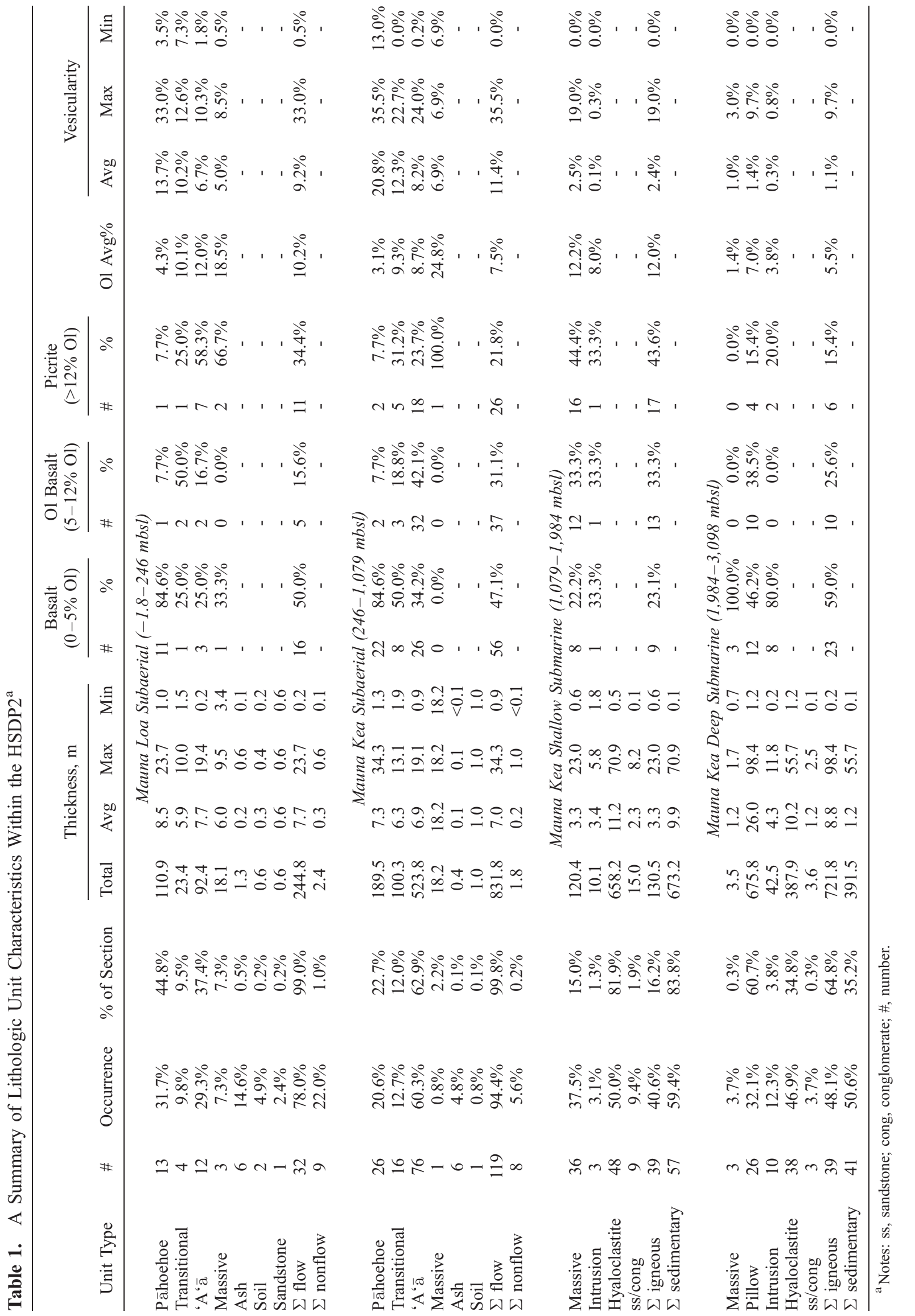


prh.noaa.gov/hnl/climate/phto_clim.php) to allow new lavas to bake (i.e., oxidize and redden) the underlying flows in most cases. In contrast, baked contacts are absent between successive flows from the current eruption of Kìlauea, even in wet areas. Therefore unbaked contacts between flows with similar mineralogy were interpreted as internal flow contacts (i.e., multiple flows from the same eruption); internal contacts are numerous within some flow units (e.g., unit 15 with 13 internal flow contacts; Table S1). Baked zones allowed easy identification of subaerial flow contacts, which was important in cases of adjacent flows with identical flow type and mineralogy (e.g., units 11, 12 , and 13).

[14] The sand deposit, unit 10 , is thin (0.6 m thick), well sorted, and contains subrounded to subangular, rock, mineral (mostly fresh olivine with some clinopyroxene and plagioclase) and variably altered glass fragments in a matrix mainly composed of clay minerals. In contrast, HSDP 1 , located only $2 \mathrm{~km}$ to the north and adjacent to the ocean (Figure 1), recovered three beach sand units, four hydroclastite deposits, and a $\sim 25 \mathrm{~m}$ thick carbonate unit [Beeson et al., 1996]. The rarity of such deposits in the shallow HDSP2 core suggests that the HSDP2 drilling site was above sea level for almost all of the last 100,000 years.

\subsection{Mauna Loa-Mauna Kea Contact}

[15] The first major chemostratographic boundary in the HSDP2 drill core is between Mauna Loa and Mauna Kea lavas at 246 mbsl (Figure 4). This boundary was found at a slightly deeper depth $(\sim 280 \mathrm{~m})$ in the HSDP1 core [Rhodes, 1996]. The greater depth may reflect the slightly greater distance $(\sim 1 \mathrm{~km})$ of the HSDP1 drill site from the summit of Mauna Kea. Chemical analyses indicate that the transition from Mauna Loa to Mauna Kea in the HSDP2 section is abrupt, with no interfingering of lavas from the two volcanoes [Rhodes and Vollinger, 2004]. Ar-Ar ages for lavas from both sides of the boundary indicate that it represents a major time gap (at least $100 \mathrm{ka}$ [Sharp and Renne, 2005]). However, there is no significant lithologic indication of this time break between units 41 and 42 (Table S1). It is marked by a baked rubble zone (Figure 4) similar to the many other baked zones in the Mauna Loa and Mauna Kea sections. Thus this zone was not recognized as a major time break during core logging; instead, a soil (unit 38) was originally picked by the logging team as the Mauna Loa-Mauna Kea contact [Hawaii Scientific Drilling Project, 2000]. However, rocks above and just below this soil have compositions typical of Mauna Loa [Rhodes and Vollinger, 2004]. Thus unit 38 represents a significant time break.

\subsection{Subaerial Mauna Kea (246-1079 mbsl)}

[16] This depth interval contains 289 flows divided into 119 flow units (with a total thickness of $832 \mathrm{~m}$ ) and 7 sedimentary units (six ashes and one soil, totaling $1.4 \mathrm{~m}$ in thickness; Table 1). The upper $\sim 96 \mathrm{~m}$, with 20 interbedded weakly alkalic and tholeiitic lavas, is part of Mauna Kea's postshield sequence [Rhodes and Vollinger, 2004]. Only one flow in this sequence (unit 48 at $\sim 277 \mathrm{mbsl}$ ) was dated, yielding a preferred Ar-Ar age of $236 \pm 16 \mathrm{ka}$ [Sharp and Renne, 2005]. Combining ages for lavas from the HSDP1 and HSDP2 cores, Sharp and Renne [2005] inferred an accumulation rate of $0.9 \pm 0.4 \mathrm{~m} / \mathrm{kyr}$ for the postshield section. On the basis of this estimate, the HSDP2 postshield sequence accumulated over $\sim 100 \mathrm{kyr}$ and had a flow recurrence interval of $\sim 5 \mathrm{kyr}$, somewhat longer than for the overlying Mauna Loa section. However, only one soil was recovered (unit 51, $1.0 \mathrm{~m}$ thick) on an ' $\mathrm{a}$ ' $\overline{\mathrm{a}}$ flow. The absence of ash units in this sequence probably inhibited soil formation during the $\sim 5 \mathrm{kyr}$ between deposition of successive flows.

[17] A thin ash (unit 64, <0.1 m thick) separates postshield and shield lavas (Table S1). The 100 subaerial lavas beneath this soil are all tholeiitic [Rhodes and Vollinger, 2004]. Only one of these tholeiitic lavas (unit 155) was successfully dated; it yielded an Ar-Ar age of $370 \pm 180 \mathrm{kyr}$ [Sharp and Renne, 2005]. The estimated accumulation rate for this section, based on combining ages from the HSDP1 and HSDP2 sections, is $8.6 \pm 3.1 \mathrm{~m} / \mathrm{kyr}$ [Sharp and Renne, 2005]. Thus this $738 \mathrm{~m}$ thick section formed over $\sim 86 \mathrm{kyr}$ and its flow recurrence interval was $\sim 860$ years, comparable to that of the recent rate for the $\mathrm{K} \overline{1}$ lauea shield $(\sim 1000$ years [Holcomb, 1987]). Although four ashes are present in this sequence (Table S1), no soils were recovered. This probably reflects the relatively short time interval between flows during Mauna Kea's subaerial shield-building stage.

\subsection{Upper Submarine Mauna Kea (1079-1984 mbsl)}

[18] The subaerial to submarine transition in the HSDP2 section is marked by the first occurrence of basaltic hyaloclastites (Table S1; Figure 4). This transition zone includes a $12 \mathrm{~m}$ thick subaerial flow (unit 168) overlying a $1.7 \mathrm{~m}$ thick, poorly indurated 
hyaloclastite (unit 169) and a thin (2.2 m), massive flow (unit 170). All three units have the same sparsely olivine-phyric to aphyric mineralogy (Table S1), and they may thus be part of one eruptive sequence. The subaerial flow is capped by a reddish, baked ash. No reddish zones were found below $1079 \mathrm{mbsl}$, so the switch from submarine to subaerial volcanism was abrupt at the HSDP2 site. This depth is also marked by a significant decrease in vesicularity (Figure 3 ) and increase in lava density [DePaolo et al., 2001; Moore, 2001]. None of the lavas from this sequence were successfully dated. However, extrapolation of the ages for lavas from the subaerial sections of the HSDP1 and HSDP2 cores lead to an estimated age of $\sim 400 \mathrm{kyr}$ for the HSDP2 subaerial-submarine transition [Sharp and Renne, 2005]. This age and its depth below sea level yields an average subsidence rate for the subaerial section of $2.7 \mathrm{~mm} / \mathrm{yr}$ [Sharp and Renne, 2005].

[19] Within the uppermost $61 \mathrm{~m}$ of the submarine section, relatively thin massive basalt $(2.4 \mathrm{~m}$ average thickness) and clastic sedimentary units $(3.1 \mathrm{~m}$ average thickness; dominantly basaltic hyaloclastite with one unit with rounded basalt cobbles) alternate and occur in roughly equal amounts (Table S1). Poor drilling conditions in the weakly consolidated hyaloclastite led to a decision to switch to tricone drilling in two intervals (1140$1223 \mathrm{mbsl}$ and 1243-1260 mbsl). No core or cuttings was recovered in these intervals. Below $1260 \mathrm{mbsl}$, hyaloclastites are the dominant rock type in the upper submarine section ( $\sim 88 \%$; Table S1). Clasts within these units are generally monomict and petrographically similar to the interlayered massive basalts, although they are more vesicular than the flows (Table S1). Glasses from both rock types are nearly all degassed [Seaman et al., 2004]. Thus both rock types were probably erupted subaerially and may have been part of the same eruptive sequences. The depth of emplacement of the rocks at the base of the upper submarine sequence (now at $1984 \mathrm{mbsl}$ ) can be estimated using an average subsidence rate of $2.7 \mathrm{~mm} / \mathrm{yr}$ and the inferred age of the section [Sharp and Renne, 2005]. Applying the emplacement depth correction factor [0.67*(depth-1079)] yields an emplacement depth of $\sim 600 \mathrm{mbsl}$ for the base of this zone (Bridges et al., submitted manuscript, 2007).

\subsection{Lower Submarine Mauna Kea (1984-3098 mbsl)}

[20] The start of this sequence is defined by the first appearance of pillow lava at 1984 mbsl. Pillow lava is the dominant rock type in this zone (26 units representing $\sim 61 \%$ of this zone; Table 1 ), although massive lavas are also present (3 units forming $0.3 \%$ ). Both lava types are interspersed with hyaloclastites (38 units comprising $35 \%$ of this zone) and three thin sandstone units with silty intervals (Table S1). This sequence is cut by 10 intrusive units (some of which have multiple splays; (Table S1). Sharp and Renne [2005] successfully dated four lavas from the sequence yielding $\mathrm{Ar}-\mathrm{Ar}$ ages of $482 \pm 67,560 \pm 150,683 \pm 82$ and $760 \pm 380 \mathrm{ka}$. A linear fit to these ages gives an age of $\sim 647 \pm$ $50 \mathrm{ka}$ for the base of the drill hole [Sharp and Renne, 2005]. On the basis of an assumed subsidence rate of $2.7 \mathrm{~mm} / \mathrm{yr}$ and the age versus depth relationship from Sharp and Renne [2005], this zone was deposited at depths of $\sim 600$ to $1350 \pm$ $135 \mathrm{mbsl}$.

[21] Sulfur contents of the glassy pillow margins from 1984-2140 mbsl are low ( 0.02 wt.\%), indicative of subaerial eruption. In contrast, lowsilica $\left(<50\right.$ wt. $\left.\% \mathrm{SiO}_{2}\right)$ pillow lava glasses from 2233-2488 mbsl have higher S (0.058-0.127 wt.\% [Stolper et al., 2004]). These higher S contents indicate eruption in a submarine environment of sufficient depth to inhibit S degassing (probably $>500$ mbsl [Seaman et al., 2004]), which is consistent with the depths of deposition inferred from subsidence (773-944 mbsl). The marked change in glass $\mathrm{S}$ content may suggest a change in vent location (e.g., the deeper lavas came from a submarine rift zone and the shallower units from the summit or other subaerial vents).

[22] Hyaloclastites are less abundant in this zone than in the upper submarine sequence, and they are mostly polymictic with many containing silty or sandy beds (Table 2). Monomictic hyaloclastite units do occur in this zone, but they are rare, relatively thin $(\leq 2 \mathrm{~m}$; Table 2$)$, and similar in mineralogy and glass chemistry to underlying or overlying flows (e.g., units 300 and 301; Table S1 [Stolper et al., 2004; Bridges et al., submitted manuscript, 2007]) suggesting a possibly close relationship between the hyaloclastites and adjacent flows. All of the analyzed glasses from hyaloclastite units from shallower than $2460 \mathrm{mbsl}$ are degassed [Seaman et al., 2004], despite their deposition at depths up to $\sim 925 \mathrm{mbsl}$ (based on their ages and assuming a subsidence rate of $2.7 \mathrm{~mm} / \mathrm{yr}$ ). At depths greater than $2460 \mathrm{mbsl}$, the hyaloclastites contain a mixture of degassed and undegassed glasses, commonly within the same unit (e.g., unit 332 [Seaman et al., 2004]). 


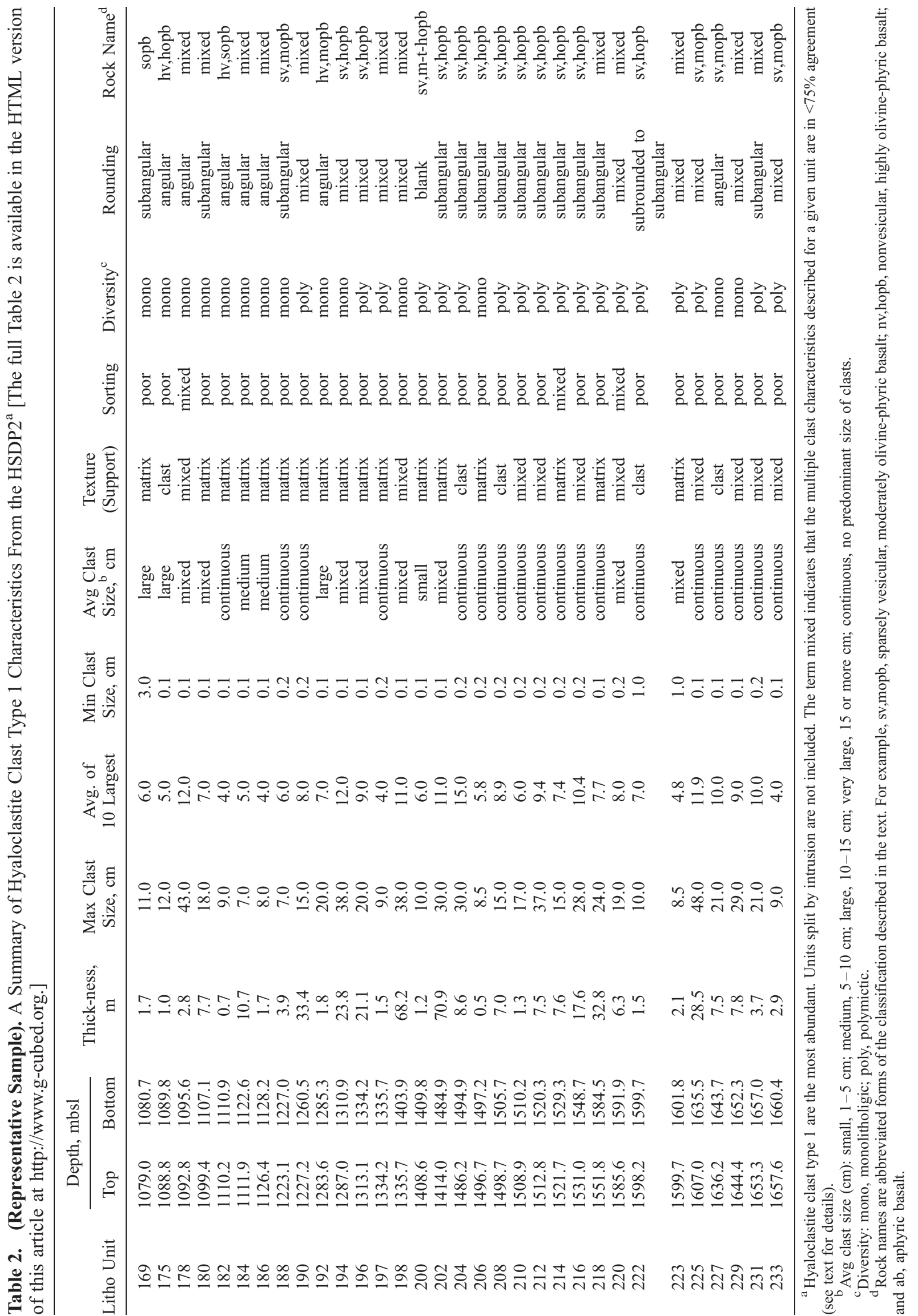




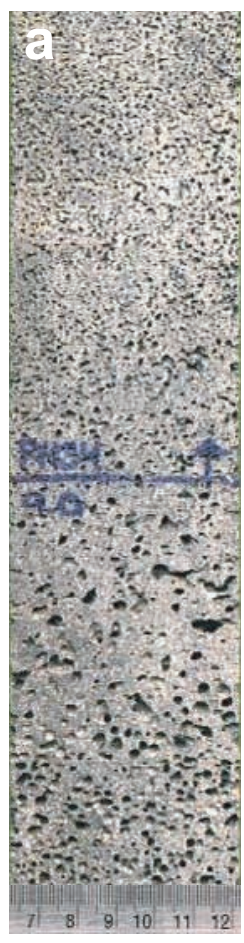

pāhoehoe

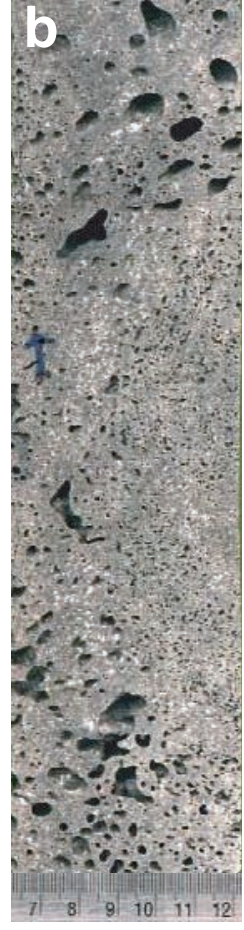

transitional

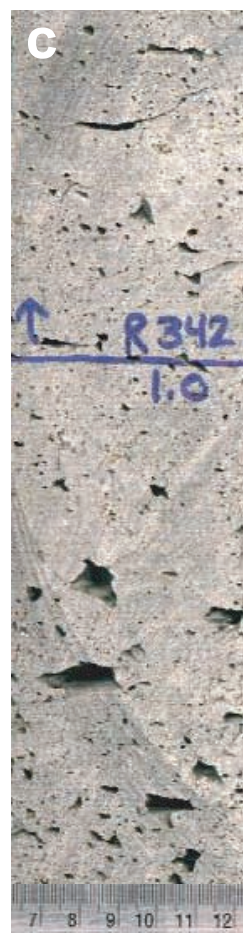

'a'à
Figure 5. Images of representative samples of lava flow types: (a) pāhoehoe, (b) transitional, and (c) ' $a ' \bar{a}$ flows. Note that these flows represent a continuum that can be seen in the gradation in the abundances and shapes of vesicles from abundant and spherical for pāhoehoe to less abundant and irregularly shaped for ' $\mathrm{a}$ ' $\bar{a}$. Arrows point upsection. Scales are in centimeters.

[23] Collectively, these features are suggestive of less frequent deposition from more distant sources than the shallower hyaloclastite units. The source lavas were probably erupted subaerially or at shallower water depths, and the debris was transported downslope several $\mathrm{km}$.

\section{Rock Type Variations}

\subsection{Subaerial Lava Flow Macroscopic Characteristics}

[24] Hawaiian lava flows are typically classified by their surface morphologies as either pāhoehoe or 'a'ā [e.g., Wentworth and Macdonald, 1953]. Unambiguous identification of flow types in drill cores can be difficult, especially if flow surfaces are not recovered, because of the one-dimensional nature of the cores [Katz and Cashman, 2003]. Following the classification scheme of Walker [1989], HSDP2 subaerial flows were considered to be pāhoehoe where glassy crusts or ropy flow tops are present and if they contain abundant spherical vesicles (see Figure 5a). 'A' $\bar{a}$ flows were distinguished by rubbly upper and/or lower surfaces, vesicle-poor interiors, and deformed and irregular vesicles (Figures 5c). The matrix of an ' $a$ ' $\bar{a}$ flow tends to be finer grained (usually cryptocrystalline in hand specimen) than that of a pahoehoe flow (microcrystalline) [Hawaii Scientific Drilling Project, 2000; Katz and Cashman, 2003]. It is important to emphasize, however, that a complete gradation exists between pāhoehoe and ' $a$ ' $\bar{a}$ flow types, so although $82 \%$ of the HSDP2 flows were unambiguously classified as one of these two flow types, it was necessary to classify $11 \%$ of the subaerial flows as transitional because they display some features of both flow types (Figures $5 b$ ), as noted in previous studies for HSDP1 [e.g., Katz and Cashman, 2003]. A fourth classification, massive, was needed for subaerial flows that lack characteristic features of pāhoehoe or ' $a$ ' $\bar{a}$. Massive flows are more common in the Mauna Loa section than in the Mauna Kea section (7 versus 2\%).

[25] HSDP2 subaerial flow units have wide ranges in unit flow thickness $(0.2-34.3 \mathrm{~m}$, averaging $7.1 \mathrm{~m}$; Table 1, Table S1). The thickest flows are compound pāhoehoe units comprising multiple inflated lobes (Table S1). Studies of Kīlauea's ongoing eruption have demonstrated that compound and inflated pāhoehoe flows are common on gentle slopes [e.g., Hon et al., 1994; Katz and Cashman, 2003]. Taking into accounts these multiflow units, the average HSDP2 Mauna Loa pāhoehoe units consist of $\sim 5$ flows, averaging $2.5 \mathrm{~m}$ thick each; those from Mauna Kea are similar, typically containing $\sim 6$ flows, averaging $1.9 \mathrm{~m}$ thick each (Table S1). 'A'ā flow units average 2.0 flows/unit and $5.4 \mathrm{~m}$ thick for Mauna Loa and 1.2 flows/unit and $6.1 \mathrm{~m}$ thick for Mauna Kea. Mauna Loa 'a'ā flows are typically 2.2 times thicker than pāhoehoe flows, whereas for Mauna Kea 'a' $\bar{a}$ flows average 3.2 times thicker on the basis of 88 Mauna Loa and 246 Mauna Kea flows. A previous estimate for Hawaiian lavas found ' $a$ ' $\bar{a}$ flows to be four times thicker than pāhoehoe flows [Walker, 1989]. Transitional flow lobes are similar in thickness and number per unit to pāhoehoe units, whereas the rare massive flow lobes are similar in thickness and number per unit to ' $a$ ' $\bar{a}$ (Table S1).

[26] Flow types in the HSDP2 Mauna Loa section are nearly evenly distributed between pāhoehoe and ' $a$ ' $\bar{a}$ (13 versus 12 flows), with a smaller number of transitional and massive flows (Table 1). This is consistent with the observation that Mauna 

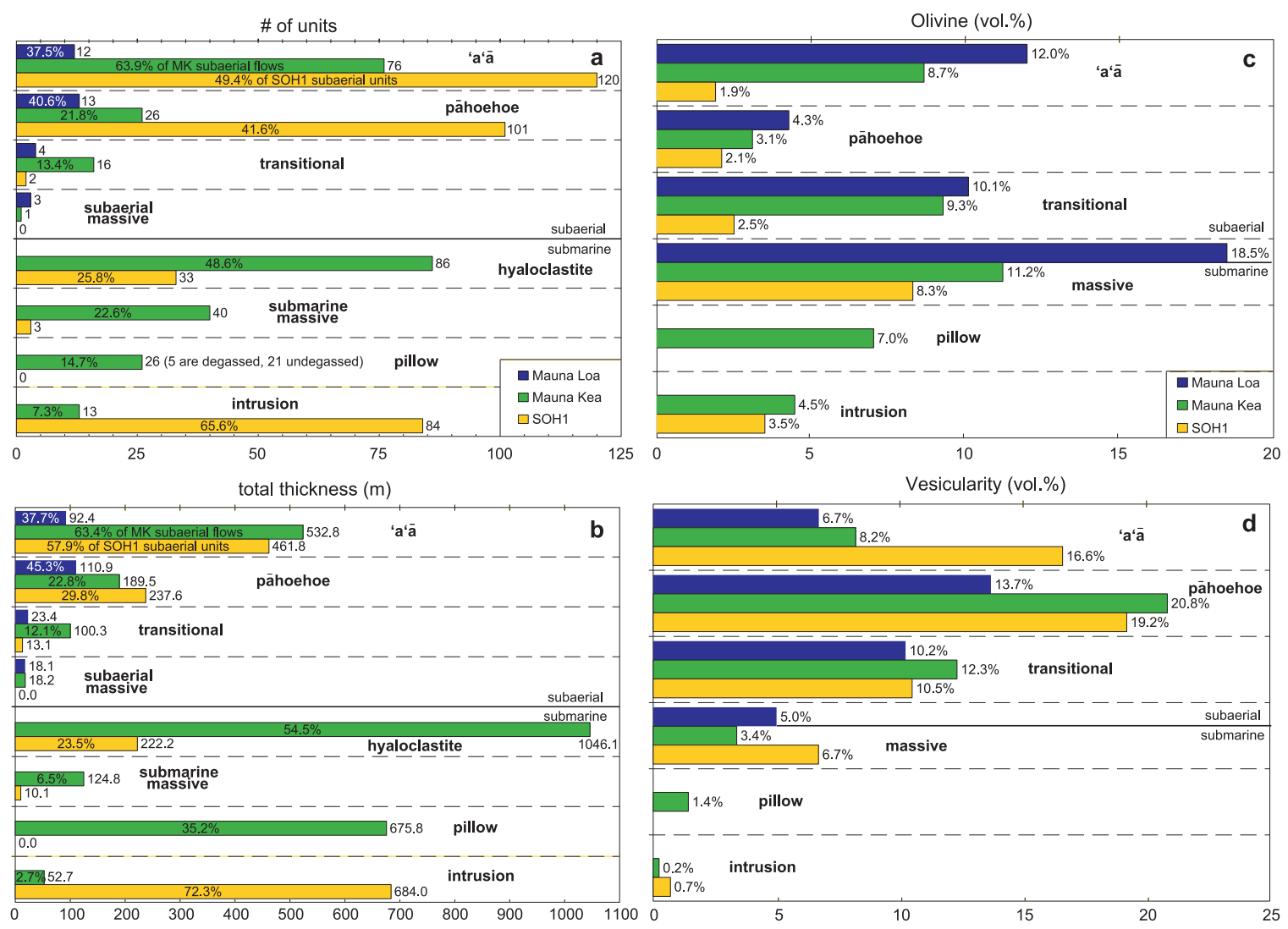

Figure 6. Comparison of HSDP2 (Mauna Kea and Mauna Loa) and SOH1 (Kīlauea) flow types: (a) number of units, (b) total thickness, (c) average vol.\% olivine, and (d) average vol.\% vesicles. Each plot is subdivided into subaerial and submarine units. Olivine and vesicle abundances are hand specimen modes in volume $\%$. Data are from Tables 1 and 4 and Tables S1 and S2.

Loa's current surface is covered almost equally by pāhoehoe and 'a' $\bar{a}$ [Lockwood and Lipman, 1987]. Although their thicknesses are similar, pāhoehoe flow units are somewhat thicker on average $(8.5 \mathrm{~m})$ than ' $a$ ' $\bar{a}$ flows ( 7.7 m; Figure 6a). Pāhoehoe comprises $45 \%$ of the Mauna Loa section versus $37 \%$ for ' $a$ ' $\bar{a}$. The $833 \mathrm{~m}$ thick subaerial Mauna Kea section has a larger amount of ' $a$ ' $\bar{a}$ ( $63 \%$ of the total flow thickness; Figures 6 and 7). However, ' $a$ ' $\bar{a}$ is more abundant from 246-809 mbsl (75\%), whereas pāhoehoe is more abundant from $809-1079$ mbsl (60\%; Table S1). Similar flow type distributions have been observed on Kîlauea and Mauna Loa, with ' $\mathrm{a}$ ' $\overline{\mathrm{a}}$ dominant on steeper subaerial shield slopes $\left(10-15^{\circ}\right)$ [Lockwood and Lipman, 1987], whereas pāhoehoe is more common on the gently sloping $\left(<5^{\circ}\right)$ coastal areas of Mauna Loa and Kîlauea [e.g., Katz and Cashman, 2003].

[27] The average olivine phenocryst content of subaerial Mauna Loa HSDP2 lavas is somewhat higher than that of subaerial Mauna Kea HSDP2 lavas on the basis of the hand specimen modes (10.2 versus 7.5 vol.\%; Figures 3 and 8), although olivine content is highly variable for each volcano. There is, however, a correlation of olivine abundance with flow type. Pâhoehoe lavas from both volcanoes tend to have much lower olivine phenocryst contents $(3-4$ vol.\%) than ' $a$ ' $\bar{a}$ and transitional flows (9-12 vol.\%; Table 1). The most olivine-rich flows for both volcanoes are the massive lavas, averaging $\sim 18$ and $\sim 25$ vol.\% olivine (Table 1). Normalization to vesicle-free olivine abundances does not change these results.

[28] Vesicularity in HSDP2 subaerial flow units is highly variable, even within individual units. On average, vesicularity is relatively low $(\sim 11 \%)$ compared to typical Hawaiian basalts (up to 6070 vol.\% in some pāhoehoe lavas [Walker, 1989]). Mauna Loa and Mauna Kea flows have similar and overlapping ranges in vesicularity $(0.5-33$ vol. $\%$, averaging $9.2 \%$ versus and $0-35$ vol. $\%$, averaging $11.4 \%$, respectively; Table 1$)$. 'A' $\bar{a}$ flows from the two volcanoes also have overlapping vesicularity ranges and similar average vesicularities (Mauna Loa $6.7 \%, 1.8-10.3$ vol.\% versus Mauna Kea $8.2 \%, 0.2-24.0$ vol.\%; Table 1, Figure 9). How- 


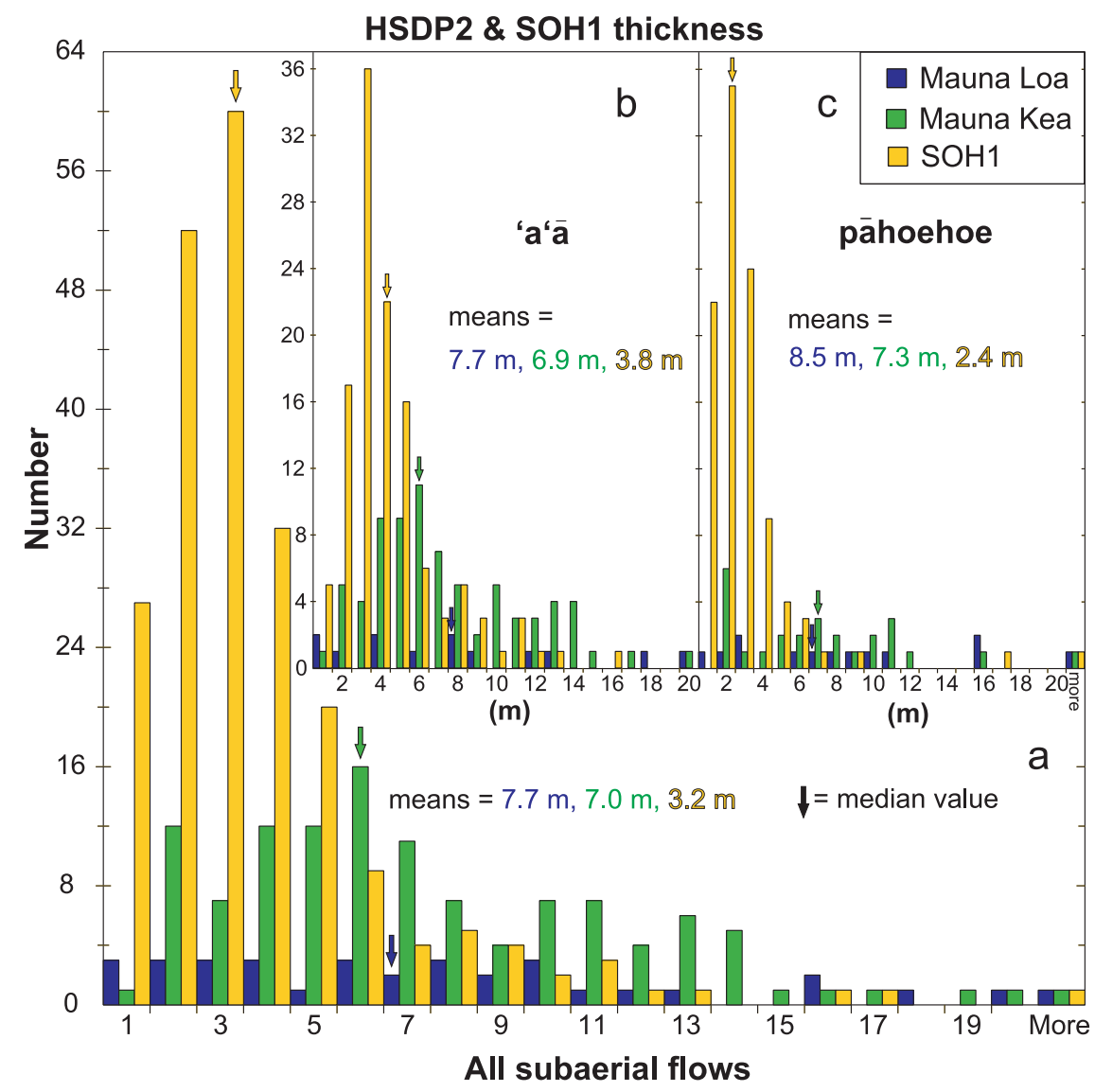

Figure 7. Histograms of subaerial flow thicknesses in HSDP2 and SOH1 drillcore: (a) all subaerial lava flows, (b) ' $\mathrm{a}$ ' $\bar{a}$ flows only, and (c) pāhoehoe flows only. Median values are indicated by the downward pointing arrows color coded for each volcano. Note that Mauna Kea and Mauna Loa lavas are thicker than the near-source (KERZ) flows of Killauea, which may be a consequence of the HSDP2 flows having traveled greater distances from their source vents. Bins start at left with 0 to $1 \mathrm{~m}$ thickness. Data are from Tables S1 and S2.

ever, the average vesicularity of pāhoehoe flows from Mauna Loa lavas is significantly lower than that of Mauna Kea pāhoehoe flows (13.7 versus 20.8 vol.\%; Table 1; Figures 3 and 9), particularly in the thicker pāhoehoe lavas. The relatively low vesicle contents of the HSDP2 lavas, especially those from Mauna Loa, are possibly due to significant volatile release during the lengthy transport from their vents to the location of the drill site. Such degassing is commonly observed during the eruption of Hawaiian basalts [e.g., Swanson, 1973].

\subsection{Submarine Rock Macroscopic Characteristics}

\subsubsection{Volcaniclastic Sediments (Hyaloclastites, Sandstones, Siltstones, Conglomerates)}

[29] The average HSDP2 hyaloclastite unit is $\sim 11 \mathrm{~m}$ thick (Table 1), although most are thinner (median $=7 \mathrm{~m}$ ) and one is $\sim 71 \mathrm{~m}$ thick (Figure 10). We emphasize, however, that in contrast to the relatively well-defined flow and unit boundaries in the subaerial part of the section, unit boundaries in the hyaloclastites are somewhat subjective and may mask internal heterogeneity (e.g., unit 285 shows an abrupt change in glass composition $2 \mathrm{~m}$ above its base, which may mark a new unit [Stolper et al., 2004]). Bedding is observed within some units with dips up to $20^{\circ}$, although most are $<10^{\circ}$. Clasts in the hyaloclastite units are lithologically and chemically similar to some adjacent massive flows (Table S1) [Stolper et al., 2004], although they are generally more vesicular. In addition, clast size and diversity increase with unit thickness. A distinctive feature of the hyaloclastites is the high abundance of translucent, brown glass (sideromelane) fragments (Bridges et al., submitted manuscript, 2007).

[30] A typical hyaloclastite unit contains multiple clast types (polymict), is matrix-supported and 


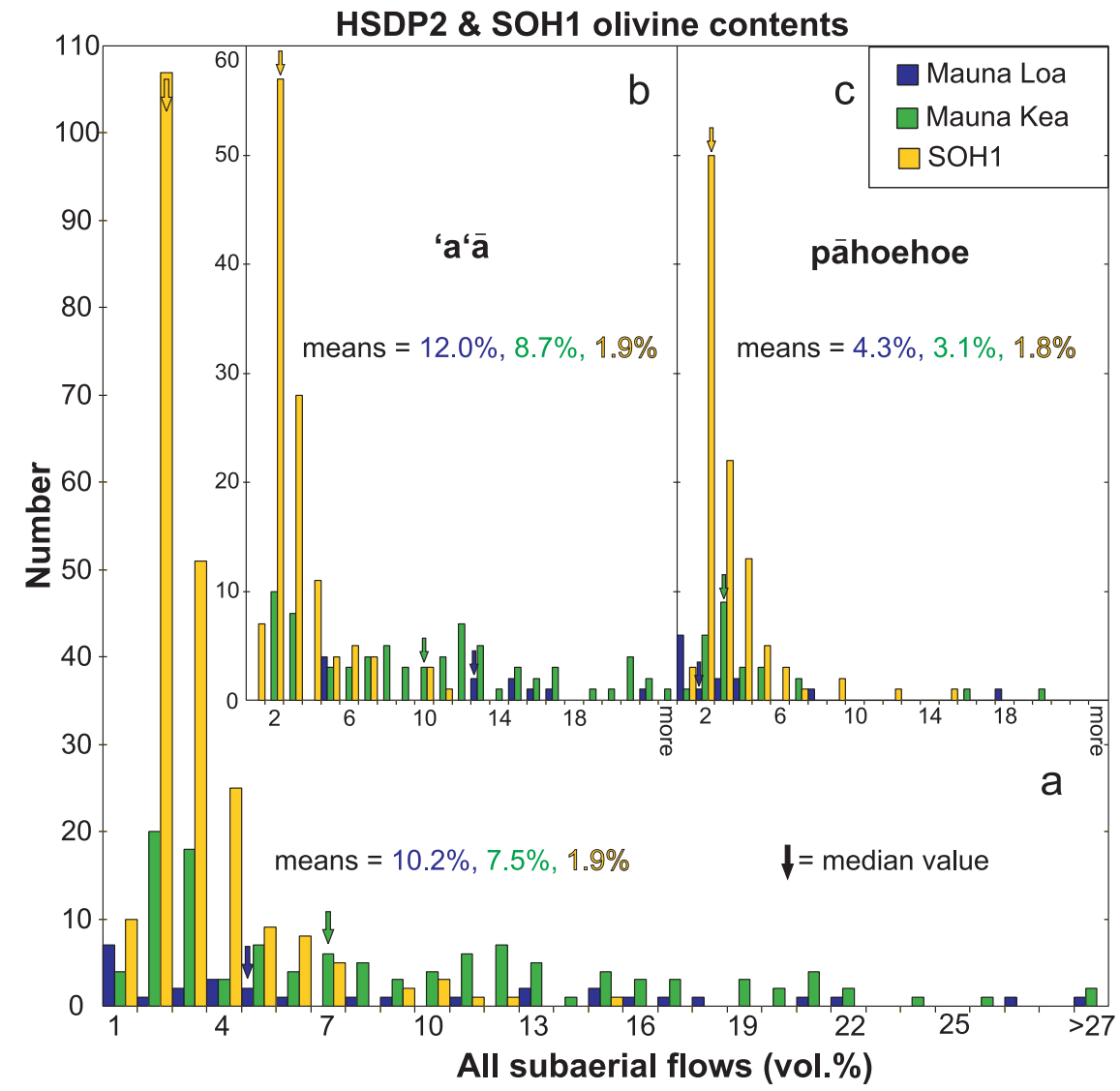

Figure 8. Histograms of olivine content (vol.\%) in HSDP2 and SOH1 subaerial lava flows based on uncorrected hand specimen modes: (a) all subaerial flows, (b) 'a'ā flows only, and (c) pāhoehoe flows only. Median values are indicated by the downward pointing arrows color coded for each volcano. Note that pāhoehoe flows have similar olivine abundances regardless of their source volcano, whereas the olivine contents of ' $a$ ' $\bar{a}$ flows increase with increasing distance from possible vent source for SOH1 (KERZ), Mauna Kea (flank), and Mauna Loa (coastal flank). Bins start at left with 0 to $1 \mathrm{~m}$ thickness. Data from Tables S1 and S2.

poorly sorted, and has abundant, subangular clasts containing olivine in variable abundance and size (Table 2 and Figures 11 and 12). However, clast diversity, type of support, and degree of sorting all change in the depth interval 1880-1980 mbsl (Figure 13). This depth interval is also where the first intrusions and pillow lavas occur, and where there is a major change in glass chemistry (zones 1-2 of Stolper et al. [2004]). The hyaloclastites in the upper part of the submarine section tend to be poorly sorted and clast-supported (Table 2; Figure 13). The shallowest eight hyaloclastite units are also all monomict and relatively thin (most are $<4 \mathrm{~m}$; Table 2, Figure 13), which is typical of the upper submarine section ( $71 \%$ are monomict). Deeper than 1984 mbsl, polymictic units generally contain three distinct clast types and only two monomict units were identified (Table 2). The relatively low vesicularity of the clasts in these units, their high glass content, and clast shape analyses led Bridges et al. (submitted manuscript, 2007) to conclude that the HSDP2 hyaloclastites were derived from fragmentation of flows underwater. The low glass $\mathrm{S}(<0.03$ wt. $\%)$ and $\mathrm{H}_{2} \mathrm{O}$ contents $(<0.2$ wt.\%) of most of the hyaloclastite glasses, especially in the upper part of the submarine section, suggests that the source flows were erupted subaerially [Seaman et al., 2004].

[31] HSDP2 submarine volcaniclastic sediments include a $1.1 \mathrm{~m}$ thick conglomerate (unit 173, $1087 \mathrm{mbsl}$ ) near the submarine-subaerial contact. This conglomerate contains subrounded lava clasts up to $25 \mathrm{~cm}$ in length in a sandy matrix, much like deposits on many Hawaiian beaches along the windward side of Hawai'i. In addition, a $1.1 \mathrm{~m}$ thick pebbly conglomerate occurs at $1585 \mathrm{mbsl}$ (unit 219). There are also 10 submarine sandstone units ranging in thickness from 0.1 to $8.2 \mathrm{~m}$, averaging $1.6 \mathrm{~m}$ thick (Table 1). The thickest 


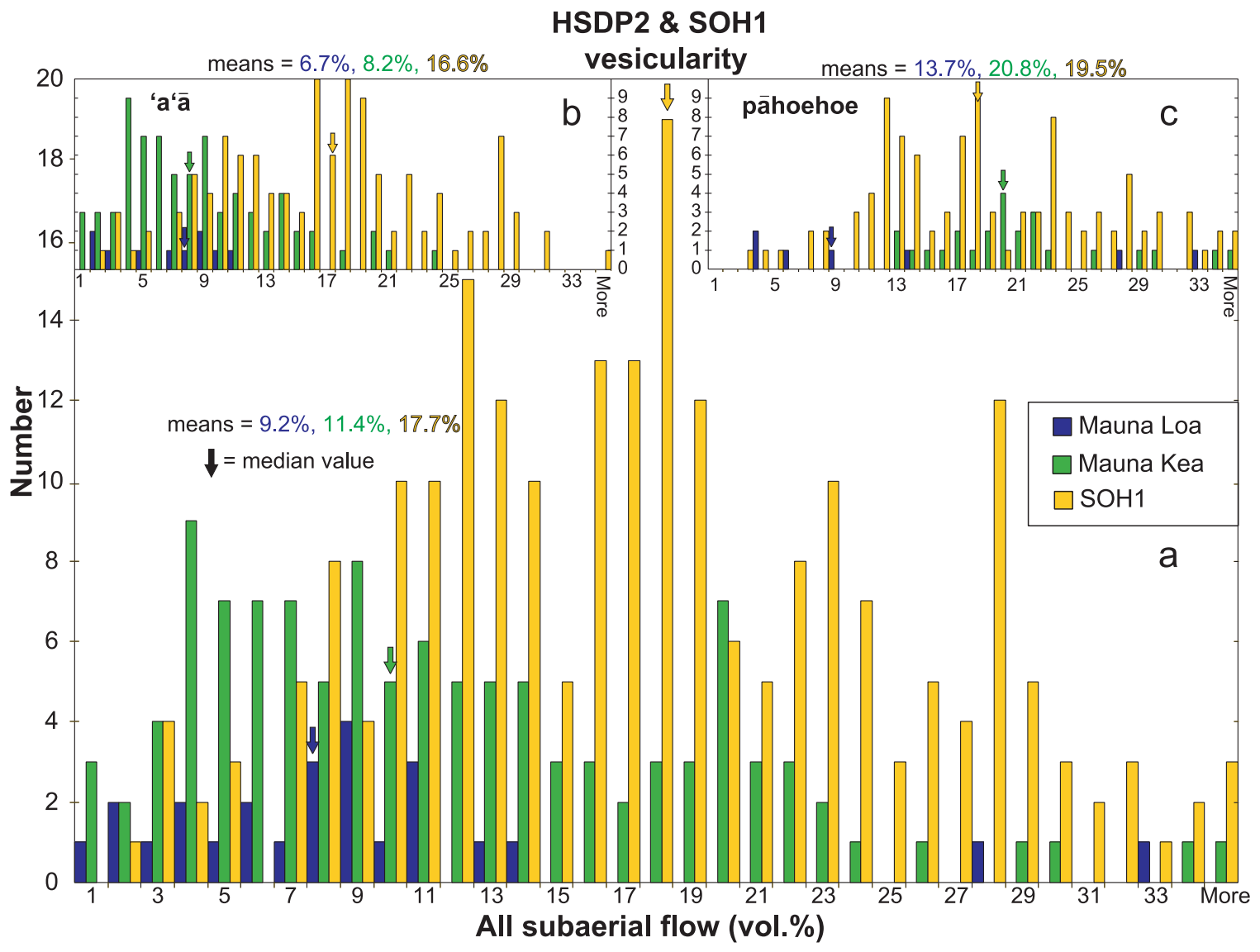

Figure 9. Histograms of vesicularity (vol.\%) in HSDP2 and SOH1 subaerial lava flows: (a) all subaerial flows, (b) ' $\mathrm{a}$ ' $\bar{a}$ flows only, and (c) pāhoehoe flows only. Median values are indicated by the downward pointing arrows color coded for each volcano. Note that vesicularity differs in ' $a$ ' a and pahoehoe flows for the HSDP2 samples (whether from Mauna Loa or Mauna Kea), whereas both flow types are similarly highly vesicular for Kîlauea. Bins start at left with 0 to $1 \mathrm{~m}$ thickness. Data are from Tables S1 and S2.

sandstone (unit 275) overlies the shallowest pillow lava at $1984 \mathrm{mbsl}$. Most of the sandstones are moderately to well sorted, with fine to medium sand, but one, unit 241, contains pebbles up to $5 \mathrm{~mm}$ in diameter. A 2-cm-long piece of carbonized wood was found in sandstone unit 259 (Figure 14). Bedding in these units is commonly defined by silty intervals dipping up to $22^{\circ}$, although most are $<5^{\circ}$. Cross-bedding was seen in two units (257 and 281). Some of these sandstones divide sections of the core with distinct compositions (e.g., units 257 and 311 [Stolper et al., 2004]), suggesting that they may represent hiatuses in eruptive activity. Sandy to silty intervals are also present within some hyaloclastite units, especially in the lower submarine section (e.g., units 255, 258, 279; Table S1).

\subsubsection{Massive Submarine Flows}

[32] Massive submarine flows are commonly interbedded with hyaloclastites to a depth of $1800 \mathrm{mbsl}$.
None are present from 1800 to $2500 \mathrm{mbsl}$ and only four occur below $2500 \mathrm{mbsl}$ (Table S1). Submarine massive flows lack pillow structures and the features normally observed in subaerial flows (e.g., red-baked contacts). They consist of single flows (except unit 251 with two flows), are thin (averaging $3.1 \mathrm{~m}$, although unit 193 is $23.0 \mathrm{~m}$ thick), olivine-rich averaging 11.2 vol.\% olivine, although successive flows can vary from 1.1 to 26.7 vol.\%), and weakly vesicular (averaging 2.5 vol.\% but ranging from $0-19$ vol.\%; Table 1, Figure 15). Vesicularity in the submarine massive flows decreases with increasing depth from a maximum of 19 vol. $\%$ to $\leq 1$ vol. $\%$ over a $200 \mathrm{~m}$ depth interval below $1110 \mathrm{mbsl}$ (Table S1). Only six of the 40 massive lavas, all located above $1140 \mathrm{mbsl}$, have $>4$ vol. $\%$ vesicles (Figure 15). Compared to subaerial Mauna Kea flows, the submarine massive flows are more olivine-rich (average 11 versus 7.5 vol.\%), thinner (average 3.1 versus $7.0 \mathrm{~m}$ ), and less vesicular 


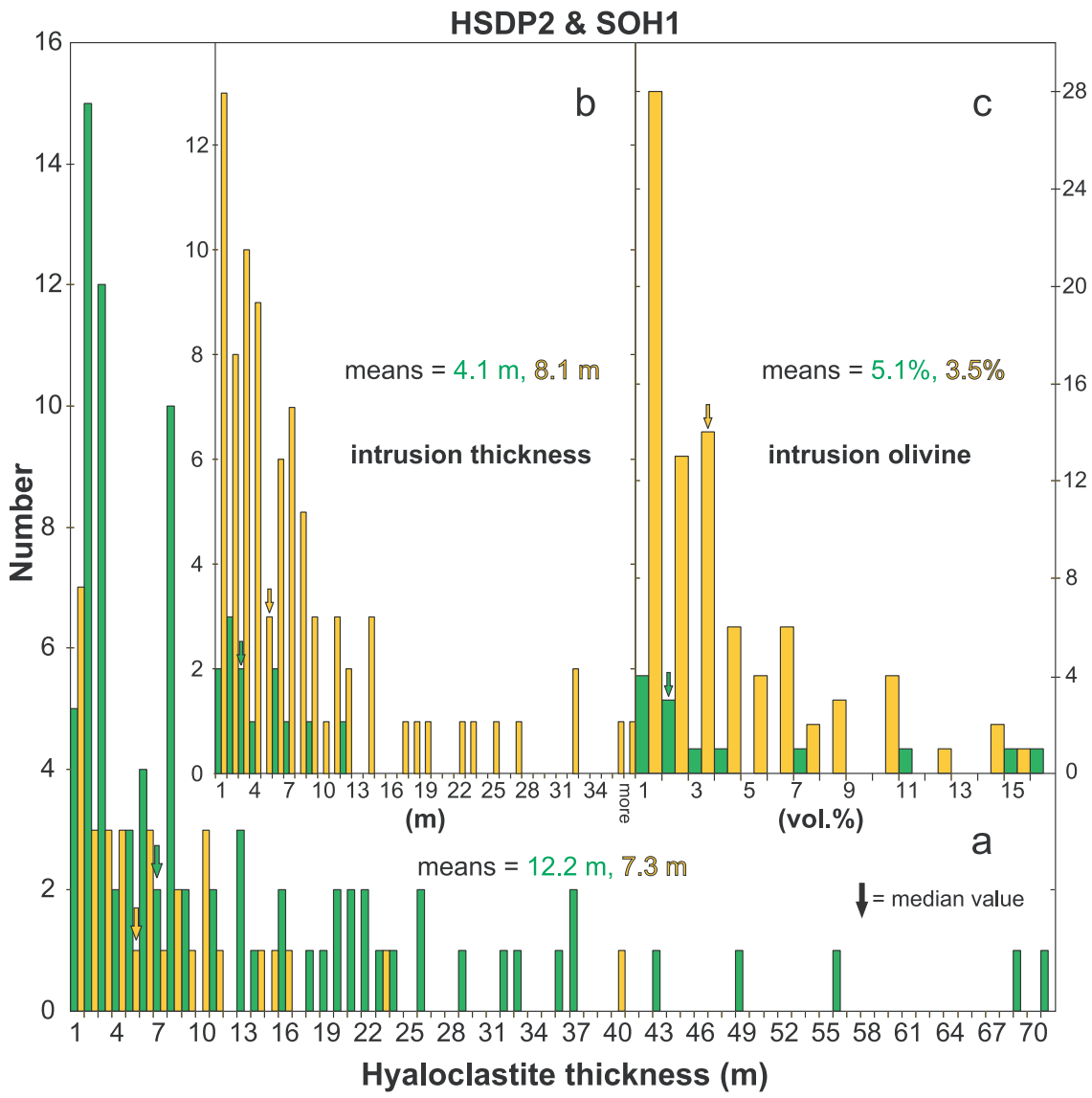

Figure 10. Histograms for HSDP2 and SOH1 core showing variations in (a) hyaloclastite thickness, (b) intrusion thickness, and (c) intrusion olivine content based on hand specimen point counts. Mean and median values are listed and labeled, respectively. The HSDP2 section has more hyaloclastite units, whereas the SOH1 section has more intrusions. Intrusions in both sections have similar olivine abundances. The SOH1 dikes are thicker because of their subvertical orientation. Data are from Tables S1 and S2.

(average 3 versus 11 vol.\%; Table 1). In the deeper submarine section (>1984 mbsl), the four massive flows are thin (average 1.2 versus $3.3 \mathrm{~m}$ ) and olivine-poor (1.4 versus 12.2 vol.\%) compared to massive flows in the upper submarine section (Table 1).

[33] The submarine massive flows may be the extensions of subaerial flows that invaded the fragmental glassy debris formed by water-lava interaction in a shallow submarine environment [e.g., Moore et al., 1973]. This is consistent with their low $\mathrm{S}$ and $\mathrm{H}_{2} \mathrm{O}$ contents [Seaman et al., 2004]. However, the total absence of pillow lavas in the upper submarine section where 36 of these flows occur and the lack of large pillow fragments in the adjacent hyaloclastites is surprising if they formed in this manner (note that the upper contact for the thickest massive flow, unit 191, was not recovered). The presence of elevated $\mathrm{H}_{2} \mathrm{O}$ in glass from the base of this unit [Seaman et al., 2004] suggests it might actually be an intrusion. However, this unit is double the thickness of any other HSDP2 intrusion and more vesicular $(3-8$ vol. $\%$ versus $<12$ vol. $\%$ for all other intrusives; Table 1). Another alternative is that these flows are sheet flows, although they lack the surface features of such flows. The origin of the HSDP2 submarine massive flows is enigmatic.

\subsubsection{Pillow Basalts and Breccia}

[34] These lavas are distinguished by well-developed, commonly curved glassy margins (Figure 11). Pillow lava units are highly variable in thickness (1-98 m; Table 1, Figure 16). The average pillow lava unit is $26 \mathrm{~m}$ thick, the thickest of any HSDP2 unit (Table 1). This may result from the difficulty in recognizing unit boundaries using only mineralogical changes. For example, the 10 thickest pillow lava units (average thickest $46 \mathrm{~m}$ ) contain 95 internal flow boundaries per unit (Table S1) with no obvious breaks in deposition. 


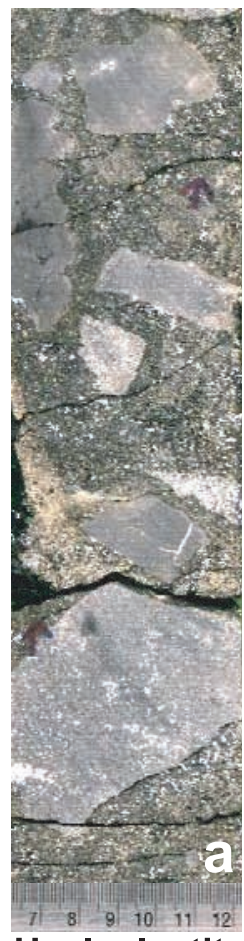

Hyaloclastite

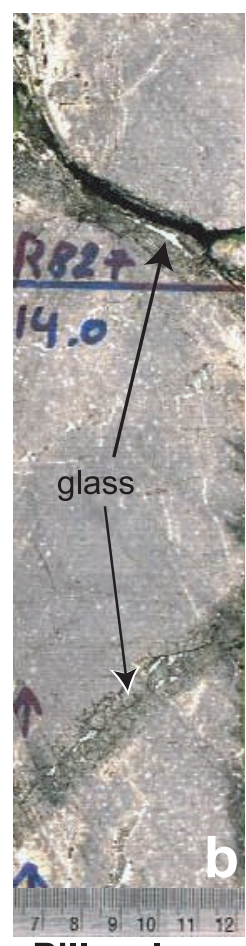

Pillow lava

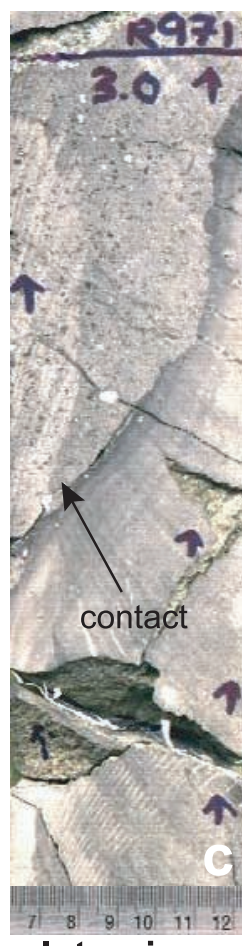

Intrusion

Figure 11. Images of representative slabs of HSDP2 submarine units. (a) Hyaloclastite with large, gray, angular to subangular clasts in a finer grained, greenishbrown glassy matrix. (b) Pillow lava lobes separated by a greenish-brown glassy rind. The three lobes of basalt illustrated have the same mineralogy and are interpreted as part of the same lithologic unit. (c) High-angle contact separating nonvesicular aphyric intrusion (to the lower right) from vesicular, olivine-rich pillow lava (to the upper left). Stubby arrows in each image point up. Scales are in centimeters.

Even the average pillow lava unit contains 31 flow lobes (Table S1). The extreme example is unit 293 (98 m thick) with 260 internal flow boundaries. Although the analyzed glasses from this unit vary in $\mathrm{MgO}$ (6.8-8.9 wt.\%), they all have low $\mathrm{SiO}_{2}$ and lie along a single line of liquid descent [Stolper et al., 2004] indicating they could be part of a single eruption (e.g., the September 1982 eruption of $\mathrm{K}$ 1lauea shows a similar $\mathrm{MgO}$ variation related to olivine fractionation [Garcia et al., 2003]). The HSDP2 pillow lavas have less olivine than the average submarine massive Mauna Kea flows (averages 7 versus 11 vol.\%) but are identical in olivine abundance to average subaerial Mauna Kea flows (Table 1). The pillow lavas have a low average vesicularity ( $1.4 \%$ ), with only two flows $\geq 5.0$ vol. $\%$ (Table S1; Figure 16). The five shallowest pillow lavas are degassed (Figure 3) and have very low

vesicularities $(<0.4 \%$ vesicles; Table S1). Glasses from the deeper pillows $(>2230 \mathrm{mbsl})$ are more volatile-rich, indicating they erupted at sufficient water depths to inhibit degassing $(>500 \mathrm{~m}$ [Seaman et al., 2004]). These pillows quenched at depths of $\sim 770-1350 \mathrm{mbsl}$ on the basis of the subsidence correction factor (Bridges et al., submitted manuscript, 2007), consistent with their higher volatile content.

[35] Thin zones $(<0.1 \mathrm{~m})$ of broken up pillow margin breccia occur throughout the pillow lava section. Three thicker breccias (units 334, 337 and $342,1.5-13.1 \mathrm{~m}$ thick; the thickest unit is intruded and broken into five subunits; Table S1) occur in the deepest part of the HSDP2 section (>2920 mbsl). Indeed, pillow breccias are the exclusive form of fragmental volcanic rock below 2920 mbsl (Table S1). The pillow breccias (whether thick or thin) are similar mineralogically to adjacent pillow lavas (Table S1) and are presumably related to these flows.

\subsubsection{Intrusive Units}

[36] Intrusive units are uncommon within the HSDP2 section; they occur only in the submarine section (Table 1). Thirteen were identified on the basis of crosscutting relationships and/or baked upper contacts (Figure 11). They represent 7.3\% of the total submarine units, but only $2.7 \%$ of the total submarine thickness (Table 1). The uppermost intrusive unit in the HSDP2 (unit 263; Table S1) occurs at a depth of $\sim 1883$ mbsl where its upper contact dips $60^{\circ}$ (Figure 3). This unit and the two that closely underlie it (units 266 and 268) intrude hyaloclastites and occur just above the uppermost pillow lava. The basal contact of these intrusions is glassy and nearly horizontal. As mentioned above, unit 191 (1260 mbsl) may actually be the uppermost intrusive on the basis of its high $\mathrm{H}_{2} \mathrm{O}$ content, although it was not classified as such because its upper contact was not recovered and it has the same mineralogy as the underlying hyaloclastite. Thus this unit was not classified as an intrusion. Ten intrusions occur in the deeper submarine section at 2511-3087 mbsl where they cut hyaloclastites and pillows (Figure 3). They commonly are splayed (e.g., unit 336 contains nine, $<1 \mathrm{~m}$ thick, petrographically similar subunits). The average intrusive unit is relatively thin $(4.1 \mathrm{~m})$, moderately olivine phyric (averaging 4.5 vol.\%, but with a wide range, $0.1-16.0$ vol.\%), and low vesicularity (averaging $0.2 \mathrm{vol} \%$, with a maximum 1.0 vol.\%; Table 1, Table S1, Figure 10). 


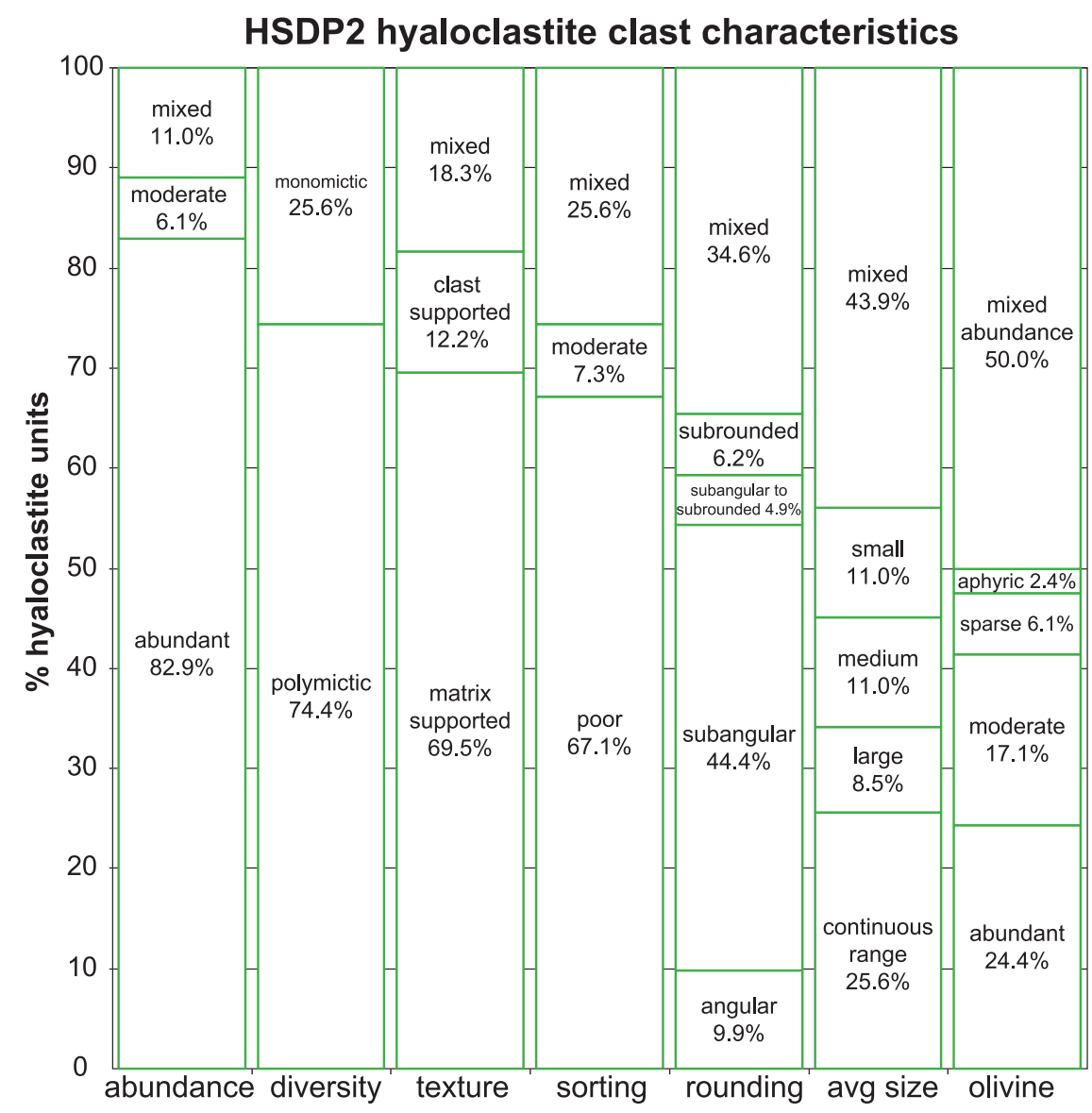

Figure 12. Summary of clast type characteristics for HSDP2 hyaloclastites. A single clast type is abundant in most units, although only $\sim 26 \%$ are monomictic. Most hyaloclastites are matrix-supported, poorly sorted, with angular to subangular clasts. There are no other clast type characteristics (average size or average olivine content) that are dominant in the majority of hyaloclastite units. Data are from Table 2.

[37] The HSDP2 intrusions are petrographically and geochemically distinct from neighboring rocks (Table S1) [Rhodes and Vollinger, 2004; Stolper et al., 2004]. Although no glass was recovered from the three shallowest intrusions, all of the deeper intrusions contain glass. The analyzed glasses contain $>0.09$ wt. $\% \mathrm{~S}$ and $>0.3$ wt. $\% \mathrm{H}_{2} \mathrm{O}$, unlike some of the adjacent pillows [Seaman et al., 2004], consistent with an intrusive origin. However, the low $\mathrm{CO}_{2}$ content of the intrusive glasses [Seaman et al., 2004] suggests they were emplaced at relatively shallow depths. Eleven of the 13 intrusions analyzed have low $\mathrm{SiO}_{2}$ glass contents ( $\left.<50 \mathrm{wt} . \%\right)$, whereas most HSDP2 submarine glasses have $>50.5$ wt.\% $\mathrm{SiO}_{2}$ [Stolper et al., 2004].

[38] The HSDP2 site was selected to be distant from known Hawaiian volcano rift zones. The closest rift is the Hilo Ridge, nearly $15 \mathrm{~km}$ to the north (Figure 1). However, interpretative cross sections of the flanks of Hawaiian volcanoes based on seismic evidence show intrusions as extending
30-40 km out from the rift zones [e.g., Hill and Zucca, 1987]. Although this interpretation could not be confirmed by the HSDP2 results, intrusive rock may increase substantially with depth. The next phase of HSDP2 drilling should help resolve the origin of the intrusions.

[39] There are several possible origins for the minor HSDP2 intrusions encountered thus far. One possibility is that they represent feeders for the radial vent flank eruptions [e.g., Lockwood and Lipman, 1987; Wanless et al., 2006] that are observed in the Hilo area related to Mauna Loa eruptions [Buchanan-Banks and Lockwood, 1982]. However, the compositions of HSDP2 intrusions are all typical of some Mauna Kea lavas and are unlike any known Mauna Loa compositions [Rhodes and Vollinger, 2004; Stolper et al., 2004]. All but one of the deeper dikes ( $>2510 \mathrm{mbsl})$ are chemically distinct to the adjacent pillow lavas and hyaloclastites (e.g., lower $\mathrm{SiO}_{2}$ ) but are similar to pillow rim glasses in the overlying zone 3 


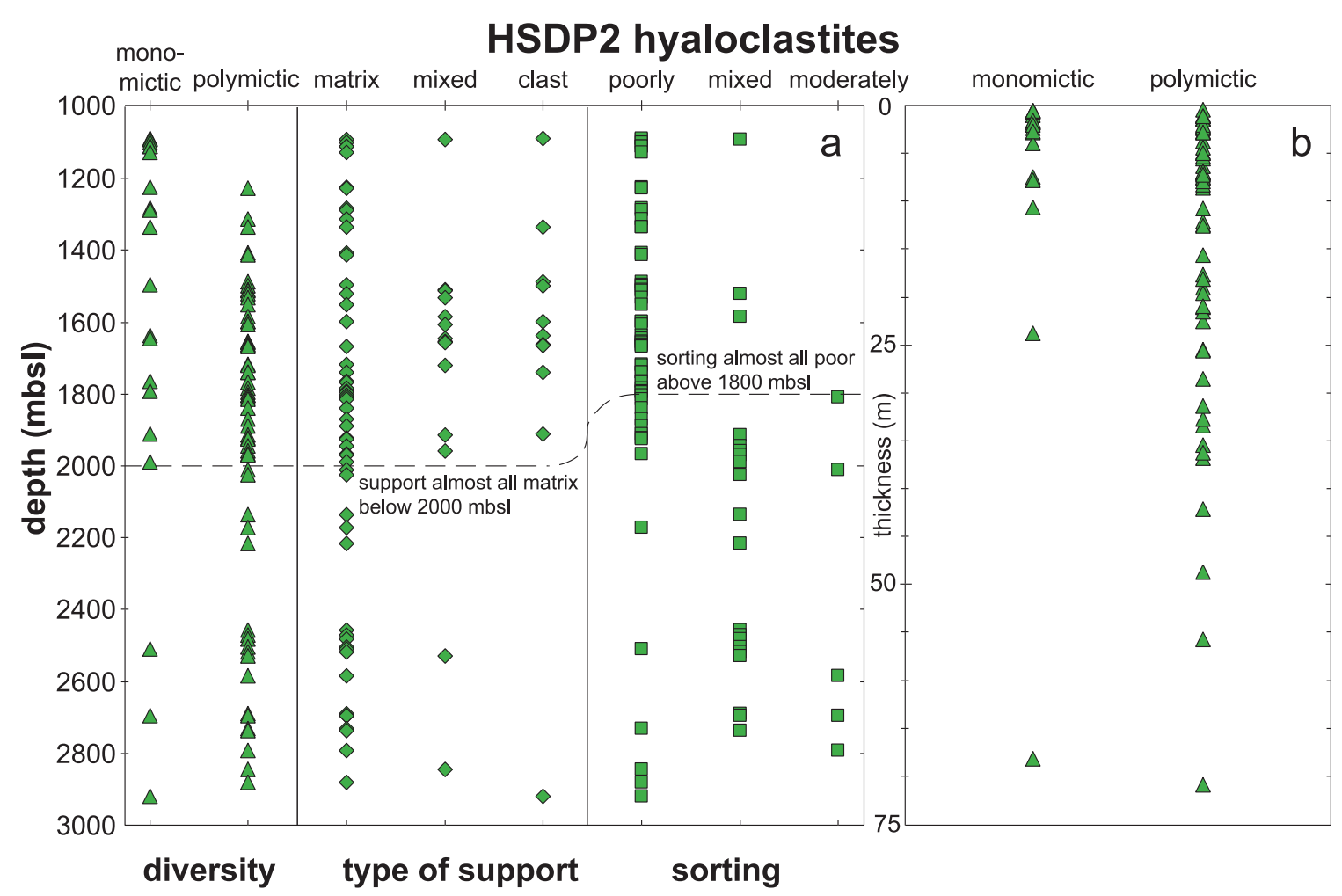

Figure 13. Variation in hyaloclastite unit characteristics with depth in the HSDP2 drill core: (a) diversity, type of support, and sorting versus depth and (b) clast diversity versus unit thickness. Many units have mixed types of clast support and sorting. More units in the upper part of the section tend to be monolithic, clast supported, and poorly sorted than in the lower part of the section. These differences may reflect increasing transport distance from source down section. Thicker units tend to have larger clasts. Data are from Table 2.

(2233-2481 mbsl [Stolper et al., 2004]). Thus they may have been feeders for the overlying pillows.

\subsection{Microscopic Petrography}

[40] All units with suitable rocks were sampled for thin sections (total of 265), which allowed more quantitative evaluation of the modal mineralogy of the HSDP2 core, xenocrysts to be identified, and crystal size (phenocryst were defined as crystals $>0.5 \mathrm{~mm}$ in width versus microphenocrysts, $0.1-$ $0.5 \mathrm{~mm}$ ) to be determined. Phenocrysts (ph) and microphenocrysts (mph) of olivine, plagioclase, and clinopyroxene are common in the HSDP2 section, with olivine dominant in almost all samples, as is typical of Hawaiian shield lavas [e.g., Macdonald, 1949]. Mauna Loa lavas are generally more olivine-rich than those from Mauna Kea (averaging 15 versus 12 vol.\%; Table 3). Among the subaerial flows, pāhoehoe typically contain much less olivine (average 8 vol.\%) than the other flow types (e.g., 'a'a, 19.5 vol.\%; Table 3 ). The average olivine content decreases within the submarine section from 15.8 vol.\% in the upper part to
8.4 vol. $\%$ in the lower portion (Table 3 ). The overall high olivine content of HSDP2 rocks is similar to lavas from the submarine flanks of Hawaiian volcanoes, where picritic basalts ( $>12$ vol.\% olivine) are abundant [e.g., Garcia et al., 1989, 1995]. In contrast, lavas from Kīlauea's summit crater have much lower olivine contents (usually $<5$ vol.\% [Garcia et al., 2003]). The abundance of olivinerich rocks on the flanks of Hawaiian volcanoes may be related to density stratification within their magmatic systems [Ryan, 1988; Garcia et al., 1995].

[41] Olivine xenocrysts (i.e., kink-banded and/or strongly resorbed crystals) are common to abundant in many HSDP2 lavas, representing $>90 \%$ of the total olivine content in some samples (Table 3). There is no systematic variation in xenocryst abundance with depth within the section or flow type (e.g., adjacent flows can vary from 0 to 24 vol.\% xenocrysts and pāhoehoe flows can contain $>20$ vol. $\%$ xenocrysts; Table 3 ). In the HSDP2 picritic basalts (i.e., $>12$ vol.\% olivine), xenocrysts comprise $\sim 60 \%$ of the olivine for the Mauna Loa 


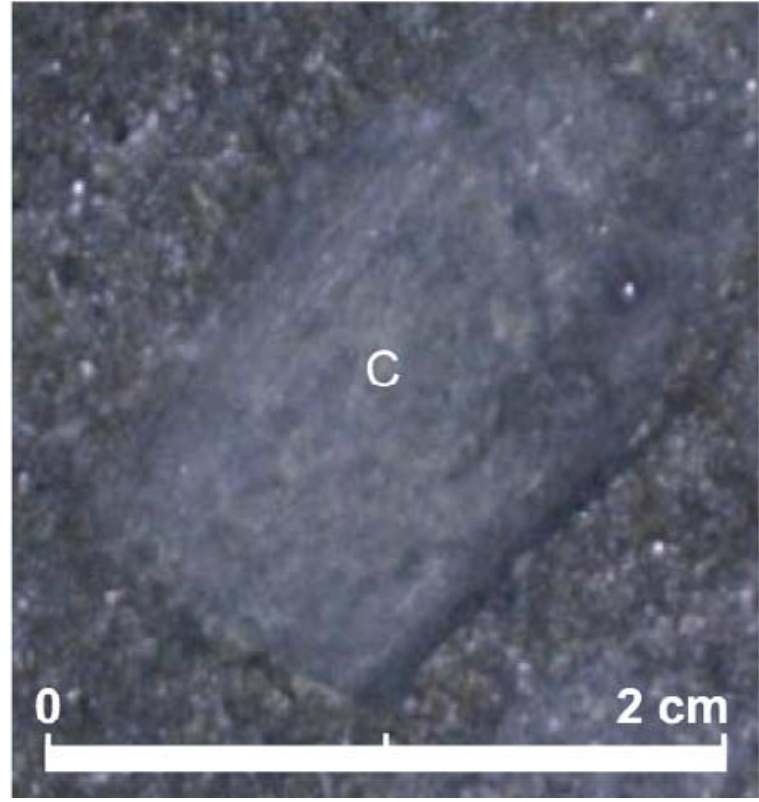

Figure 14. Carbonized wood fragment (C) set in a matrix of glassy fragments found in the HSDP2 core (hyaloclastite unit 259) at $\sim 1820$ mbsl.

and Mauna Kea subaerial sequences, and $\sim 90 \%$ in the submarine section (Table 3). Abundant olivine xenocrysts were also noted in the HSDP1 drill core and were found to have diverse compositions, most not in equilibrium with the host rock [Baker et al., 1996; Garcia, 1996]. However, the olivine xenocryst and phenocryst compositions in HSDP1 lavas completely overlap, as do their included spinel compositions [Baker et al., 1996]. It has been suggested that the olivine xenocrysts in Hawaiian lavas may represent disaggregated dunites [e.g., $\mathrm{Helz}, 1987]$. However, dunite and peridotite inclusions are rare in the HSDP core [Garcia, 1996; Hawaii Scientific Drilling Project, 2000]. The overlap in compositions of phenocrysts and xenocrysts in HSDP1 lavas led Baker et al. [1996] to suggest that the xenocrysts were entrained crystals from the lower parts of magma chamber(s) in the volcanic edifice and that although the xenocrysts did not crystallize from their host liquids, they formed from closely related liquids that passed through the same magma chambers. However, this does not easily explain why so many of these crystals are strongly resorbed and/or deformed. A possible alternative is that the wide compositional ranges of olivine xenocrysts in HSDP core reflect their derivation from numerous sources within each volcano.

[42] Total olivine abundances correlate with wholerock $\mathrm{MgO}$ contents in HSDP2 samples (Figure 17), which is common for suites of Hawaiian lavas [e.g., Wilkinson and Hensel, 1988; Garcia, 2002]. $\mathrm{MgO}$ is a standard indicator of extent of fractionation in Hawaiian lavas, and 7.0 wt.\% is the typical value for the onset of crystallization of other minerals (i.e., plagioclase and/or pyroxene [e.g., Wright and Fiske, 1971]). However, there is no obvious correlation of lower $\mathrm{MgO}$ contents with the presence of these minerals as ph or $\mathrm{mph}$ in the eight analyzed rocks with $\mathrm{MgO} \leq 7$ wt.\%; i.e., low$\mathrm{MgO}$ rocks may be aphyric (e.g., unit 42) or contain abundant ( $>5$ vol.\%) plagioclase and pyroxene ph or mph (e.g., units 46 and 305). It is interesting that only $4 \%$ of the HSDP 2 rocks would be classified as evolved on the basis of $\mathrm{MgO}$ $\leq 7$ wt. $\%$, and two are from units with heterogeneous olivine distributions (units 105 and 305). Most of the rocks with $>2$ vol.\% total plagioclase and pyroxene ph and mph have $\mathrm{MgO}>7 \mathrm{wt} . \%$, and some rocks with $>25$ wt. $\% \mathrm{MgO}$ have abundant plagioclase and pyroxene ph and mph ( $>6$ vol.\%; units 171 and 179). In the latter cases, the plagioclase and pyroxene are strongly zoned or corroded, probably indicating disequilibrium related to magma mixing, as found previously in submarine Mauna Loa picrites [e.g., Garcia et al., 1995]. Thus the presence of plagioclase and/or pyroxene phenocrysts is not a reliable indicator of the bulk composition of the rock, although modal olivine content is helpful.

[43] Five of the six uppermost Mauna Kea subaerial flows are distinctive in being aphyric or weakly olivine-phyric (units 42-43, 45-48; Table 3). As described above, these lavas mark the end of Mauna Kea's postshield stage in the HSDP2 section [Rhodes and Vollinger, 2004]. Their weakly olivine-phyric character is similar to many of the Mauna Kea lavas exposed in the canyons north of Hilo, although these canyon sections also contain ankaramites [Frey et al., 1991], which are absent in the HSDP2 (Table 3) and HSDP1 sections [Baker et al., 1996; Garcia, 1996]. Among HSDP2 postshield lavas (units $42-63$ based on whole-rock geochemistry [Rhodes and Vollinger, 2004]), 72\% contain clinopyroxene ph or $\mathrm{mph}$, whereas only $33 \%$ have plagioclase (Table 3). Flows in the underlying subaerial shield section are somewhat less likely to contain ph or mph of these minerals (62\% and 29\%; Table 3), and the abundance of clinopyroxene is usually greater than plagioclase. Clinopyroxene $\mathrm{ph}$ and $\mathrm{mph}$ are more abundant in ' $a$ ' $\bar{a}$ than pāhoehoe flows (69 versus 44\%; Table 3 ), which may reflect the greater extent of crystallization in ' $\mathrm{a}$ ' $\bar{a}$, although there is no difference in 


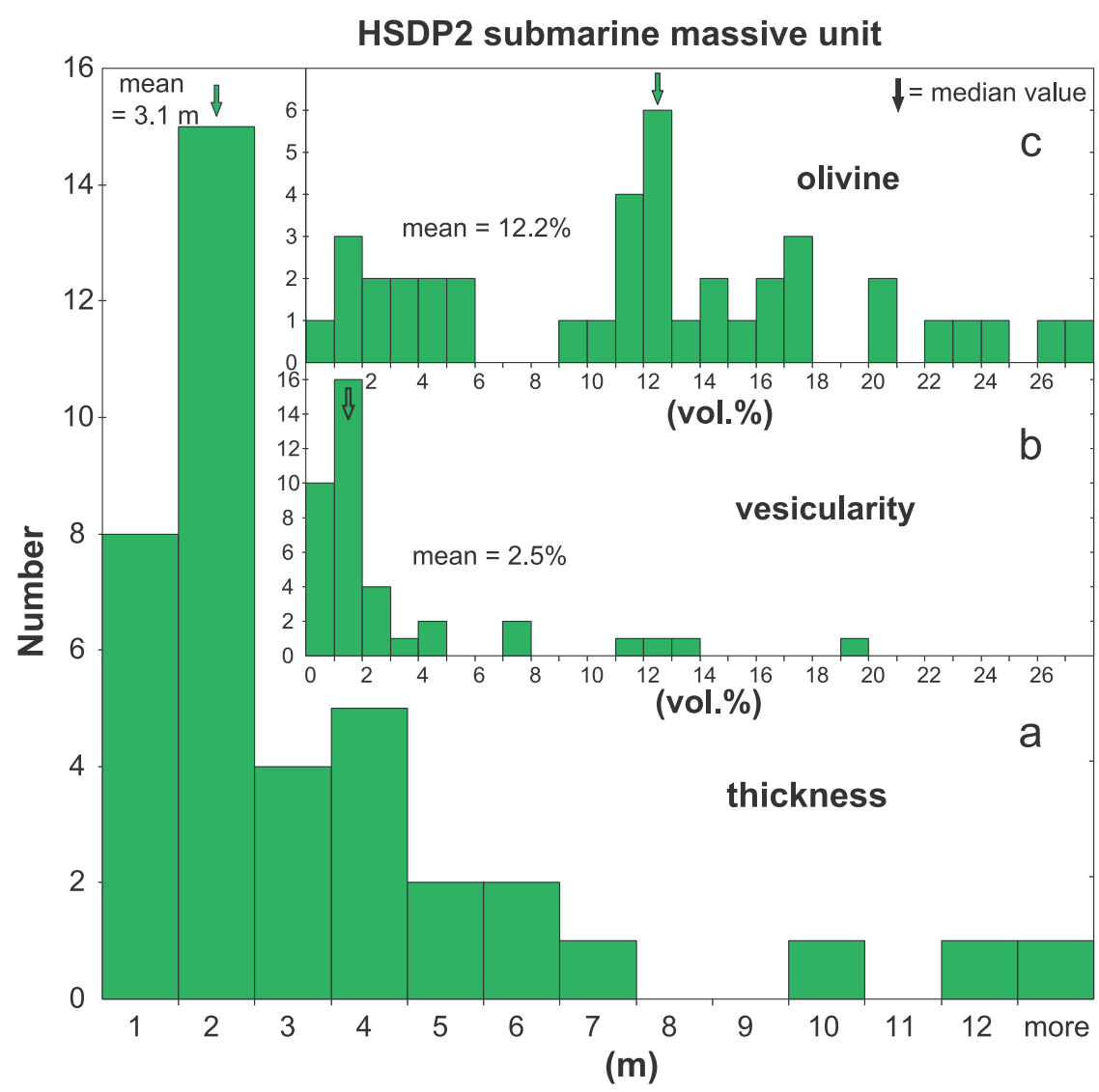

Figure 15. Histograms of variations in HSDP2 submarine massive units: (a) thickness, (b) vesicularity (vol.\%), and (c) olivine content (vol.\%). Median values are indicated by the downward pointing arrows. Bins start at left with 0 to $1 \mathrm{~m}$ thickness. These units are generally thinner, less vesicular, and more olivine-rich than adjacent hyaloclastite units. These characteristics are consistent with submarine massive flows erupting subaerially and entering the ocean nonexplosively via lava tubes [e.g., Garcia and Davis, 2001; Seaman et al., 2004]. Data are from Table 1 and Table S1.

plagioclase ph and mph occurrence with flow type ( $26 \%$ each; Table 3). Mauna Loa subaerial flows are more likely than Mauna Kea rocks to contain ph or mph of minerals other than olivine, especially plagioclase (73 versus 28\%) and orthopyroxene (31 versus 7\%; Table 3). The higher $\mathrm{SiO}_{2}$ and $\mathrm{Al}_{2} \mathrm{O}_{3}$ contents of Mauna Loa lavas [Rhodes and Vollinger, 2004] probably accounts in large part for the greater presence and abundance of these minerals in Mauna Loa lavas on the basis of MELTS calculations [e.g., Wanless et al., 2006]. Another factor may be the somewhat longer travel distance to the HSDP2 site from probable vent locations on Mauna Loa compared to Mauna Kea (37-60 versus $14-45 \mathrm{~km})$, resulting in greater cooling and therefore more extensive crystallization.

[44] The significant petrographic variations in the shallow HSDP2 submarine section appear to correlate with glass and whole-rock geochemistry. Samples between $\sim 1400-1880$ mbsl essentially only contain olivine ph and mph (cpx and plagioclase are $<0.1$ vol. $\%$; Table 3 ), consistent with the high $\mathrm{MgO}$ contents of these rocks ( $>11 \mathrm{wt} \% \mathrm{MgO}$ [Rhodes and Vollinger, 2004]). Additionally, 29 of 31 analyses in this interval are chemically similar, and classified as part of the same tholeiitic subcategory (MK-1 [Rhodes and Vollinger, 2004]). From the first occurrence of an intrusion at $1883 \mathrm{mbsl}$ to the bottom of the hole, clinopyroxene and/or plagioclase ph and mph occur in most of the units examined, with clinopyroxene almost always more abundant than plagioclase (Table 3). Many of the deep submarine rocks have lower $\mathrm{SiO}_{2}$ [Stolper et al., 2004], and all but one lack plagioclase ph or mph (Table S1). Although the absence of plagioclase is a not usually a good indicator of geochemistry, all the HSPD2 units containing plagioclase ph or mph are from the higher $\mathrm{SiO}_{2}$ compositional group MK-1 of Rhodes and Vollinger [2004], except unit 287 . Rock samples with only olivine or olivine and clinopyroxene $\mathrm{ph}$ or $\mathrm{mph}$ are either 
HSDP2 pillow lavas

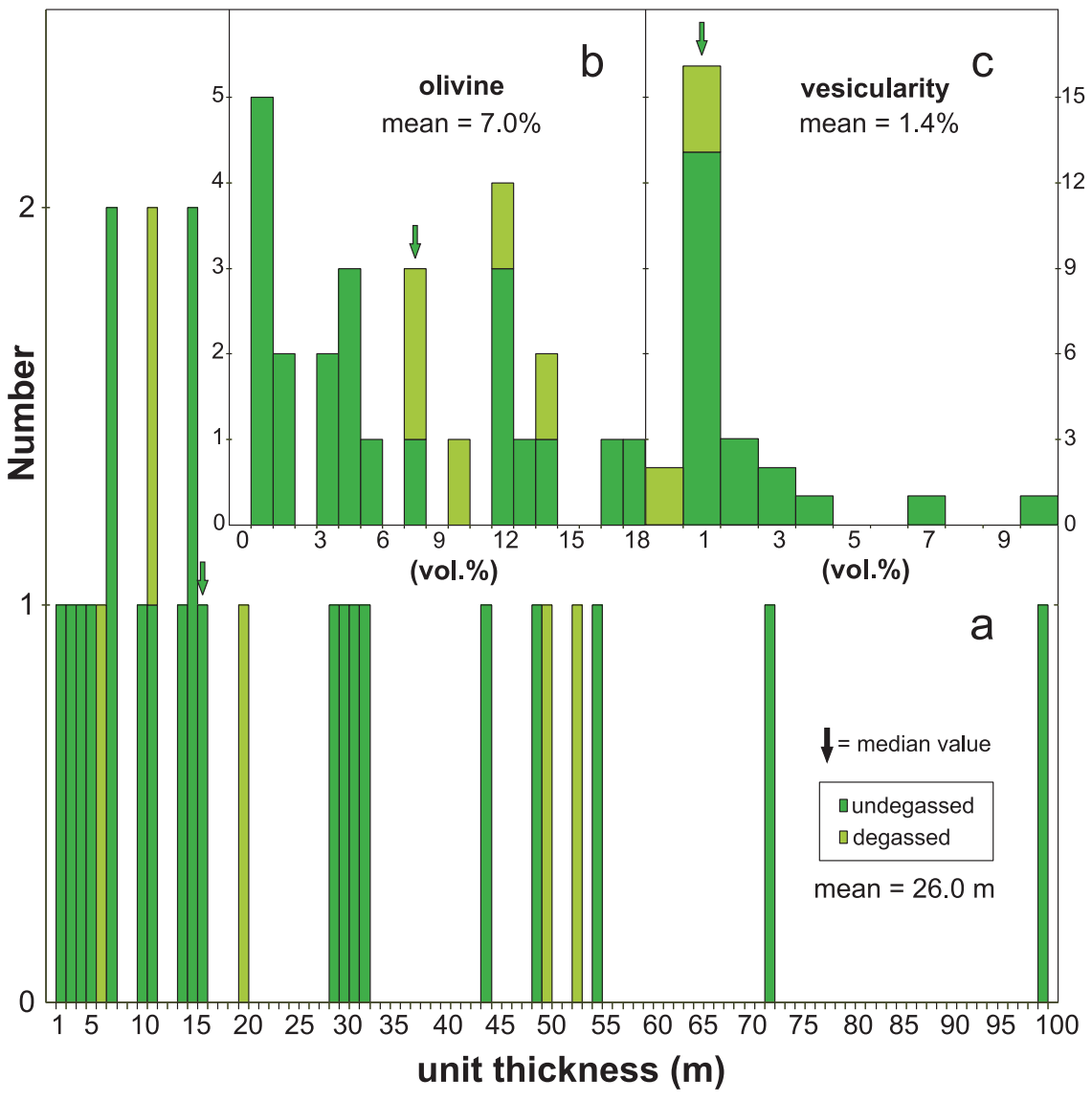

Figure 16. Histograms of variations in HSDP2 pillow lava units: (a) thickness, (b) olivine content (vol.\%), and (c) vesicularity (vol.\%). Bins start at left with 0 to $1 \mathrm{~m}$ thickness. Median values for all pillow lavas are indicated by the downward pointing arrows. There appears to be no preferential pillow lava unit thickness, although nearly all units have numerous internal glassy margins indicating multiple lobes of the same unit (Table S1). The olivine abundance distribution also has no obvious preferred value. Most of the pillows have low vesicularities with a pronounced mean at 1.4 vol.\%. Data are from Table S1 and Table 1.

the low-SiO${ }_{2}, \mathrm{MK}-3$ rock type or relatively unevolved MK-1 units of Rhodes and Vollinger [2004].

[45] Orthopyroxene phenocrysts or microphenocrysts were found in 31\% of the Mauna Loa and 8\% of Mauna Kea thin sections, including both lower and higher silica rock types (Table 3). Orthopyroxene is rare in Hawaiian basalts and is usually reported only in the relatively high $\mathrm{SiO}_{2}$ lavas from Ko'olau and Mauna Loa volcanoes [Macdonald, 1949]. Thus its common occurrence in the Mauna Loa HSDP2 lavas was expected. In lower $\mathrm{SiO}_{2}$ lavas, orthopyroxene generally occurs only in more fractionated, lower temperature lavas $(\mathrm{MgO}<6.0 \mathrm{wt} . \%$, $\left.\leq 1100^{\circ} \mathrm{C}\right)[$ Wright and Fiske, 1971; Helz and Thornber, 1987], so it is surprising to see it in some Mauna Kea samples with higher $\mathrm{MgO}$ contents.
However, many of the orthopyroxene-bearing Mauna Kea lavas show signs of magma mixing (resorbed crystals and/or complex zoning; e.g., units 191 and 263), so the orthopyroxene in the lower $\mathrm{SiO}_{2}$ rocks may have formed in evolved magmas that mixed with more $\mathrm{MgO}$-rich magmas. Similar petrographic relationships were found in submarine lavas from the Hilo Ridge [Yang et al., 1994].

\subsection{Core Alteration}

[46] Alteration of the HSDP2 core is mainly localized in vesicles, on fracture surfaces, and at the margins of olivine grains, leaving most of the lava relatively fresh. Alteration is more extensive in the submarine section, with obvious clear or white secondary minerals filling or lining cavities and fractures (Figure 18), and partial to complete 


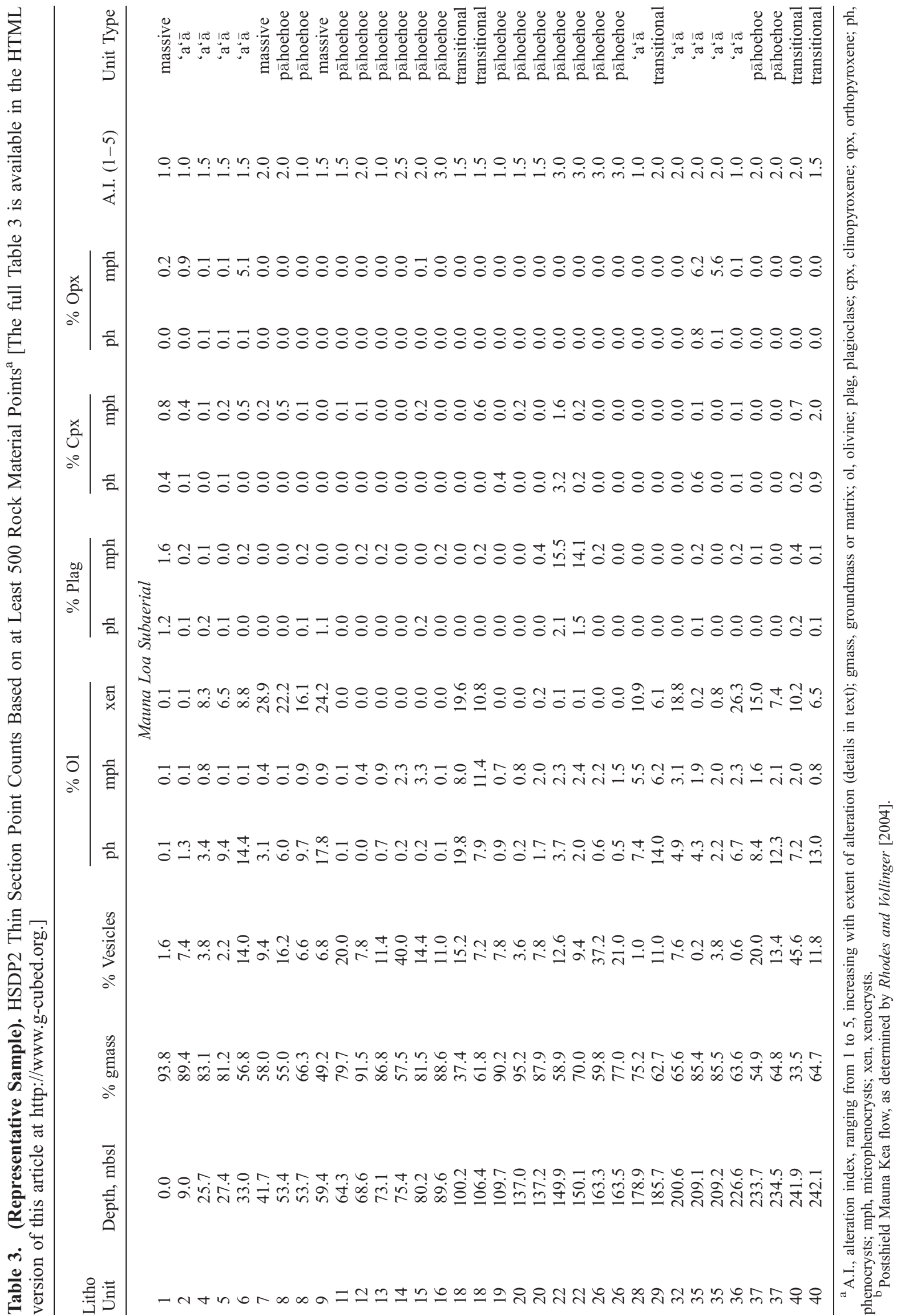




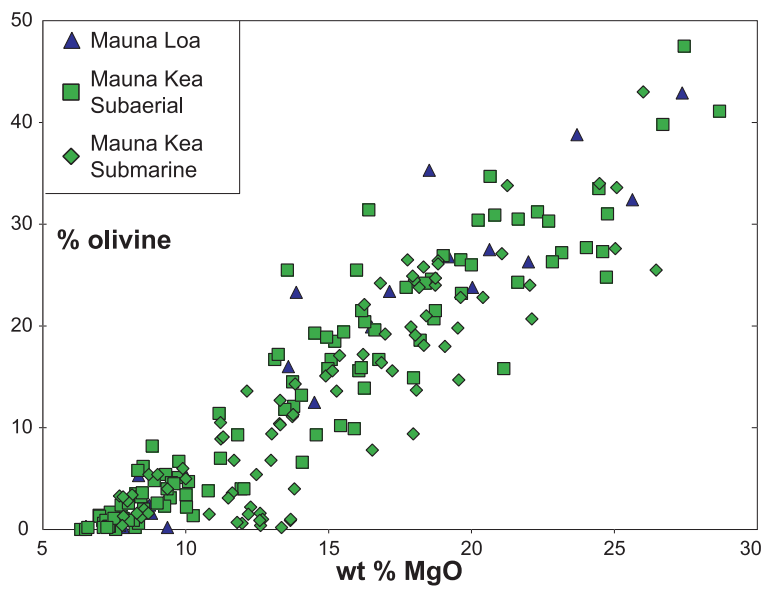

Figure 17. Plot of modal olivine abundance (from thin sections) versus whole-rock $\mathrm{MgO}$ content in HSDP2 lavas. The good correlation between these two parameters and the high content of olivine in many of these lavas indicate that many HSDP2 lavas have accumulated substantial olivine. Data are from Table 3 and Rhodes and Vollinger [2004].

replacement of glass and olivine by secondary minerals in some samples. The secondary minerals include clay (mostly smectite), several types of zeolite (most commonly chabazite and phillipsite), thaumasite, gyrolite, truscottite, gypsum (in the upper part of the submarine section; see Figure 18), and rare pyrite [Walton and Schiffman, 2003]. Halite appeared on some sections of the core after they were dried, although not as extensively as on the HSDP1 core.

[47] To assess better the extent of alteration of the HSDP2 core, thin sections spanning the full depth range of the HSDP2 core were examined (Table 3). Following the method of Quane et al. [2000], an alteration index (AI) value of 1 to 5 was assigned according to the following criteria: (1) unaltered; (2) thin $(<0.01 \mathrm{~mm})$ iddingsite rims on olivine; (3) moderate alteration of olivine (iddingsite rims $>0.01 \mathrm{~mm}$ and along cracks); (4) more extensive olivine alteration plus minor matrix alteration, and secondary minerals in vesicles; and (5) extensive matrix alteration and total iddingsite replacement of olivine (Table 3). Intermediate values were assigned (e.g., 1.5) if a thin section was variably altered and/or contained regions more or less altered than the whole (Table 3 ).

[48] Thin section examination indicates that the subaerial HSDP2 section rocks are relatively unaltered, except along cracks and in vesicles. Mauna Loa pāhoehoe lavas are somewhat more altered than interbedded ' $a$ ' $\bar{a}$ and massive flows (Figure 19). The more altered rocks have higher vesicularity (averaging 14 vol.\% versus $7-10$ vol.\%; Table 1 ), which likely promoted alteration by providing more surface area and pathways for fluids. In contrast, subaerial Mauna Kea lavas all show similar and lower levels of alteration than the Mauna Loa despite a moderate range in vesicularity (7-21 vol.\%; Table 1). Thus there is no simple correlation of alteration index with depth in the subaerial section. The greater alteration
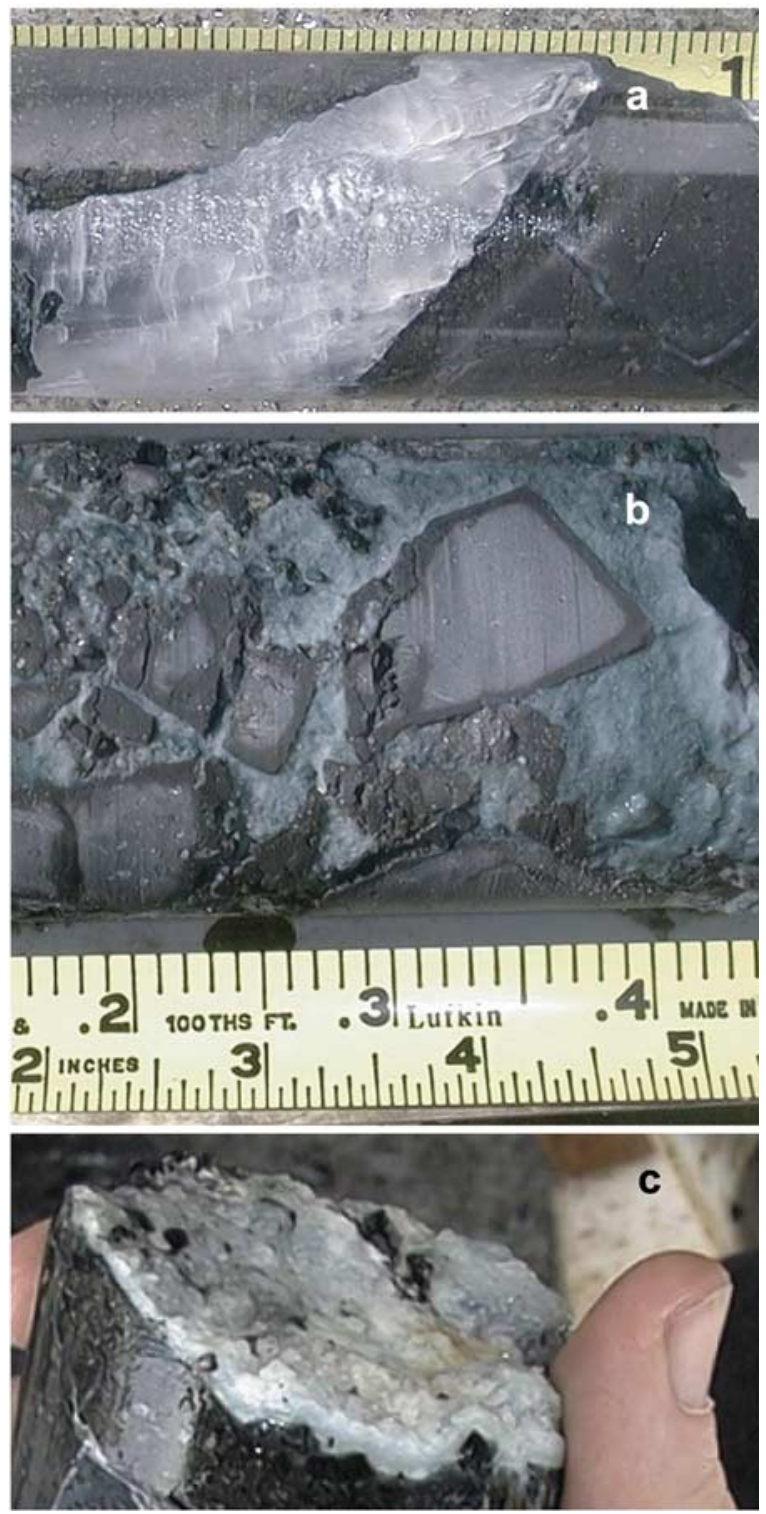

Figure 18. Examples of secondary mineralization of the HSDP2 core: (a) gypsum filling a large fracture, (b) green sulfate surrounding fragmented pillow lava clasts, and (c) white chabazite coating a fracture surface. Scale is in tenths of feet in Figure 18a and inches in Figure 18b; Figure 18c has a thumb for scale. The core is $6.4 \mathrm{~cm}$ wide. 


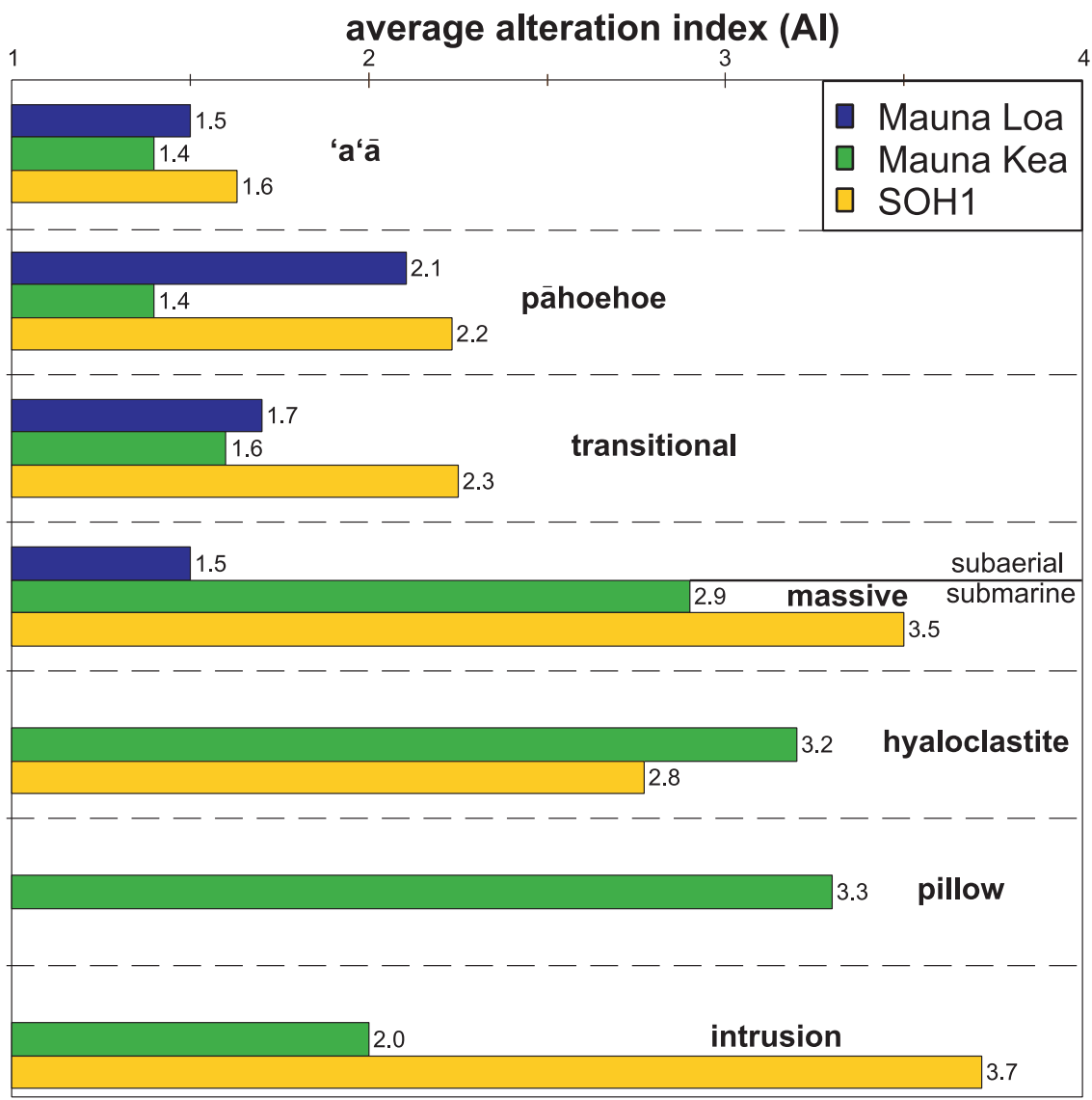

Figure 19. HSDP2 and SOH1 rock alteration index (AI) values versus flow type based on thin section examinations. See text for description of values. Subaerial pahoehoe flows are generally more altered than other subaerial rock types, probably because their higher vesicularity provided higher permeability and more surface area for reaction. SOH1 lavas are more altered than those from the HSDP2. The higher average AI values of SOH1 rocks may be related to their greater vesicularity and the abundant intrusions in the SOH1 section. Temperatures as high as $206^{\circ} \mathrm{C}$ have been recorded in SOH1 [Bargar et al., 1995]. Data are from Tables 3 and 5.

state of some Mauna Loa lavas may be related to their exposure for longer time periods before being covered by a subsequent flow $(\sim 3,000$ years for Mauna Loa versus 860 years for Mauna Kea shield lavas [Sharp and Renne, 2005]). Similarly, greater exposure time may also have played a role in the more altered nature of the uppermost Mauna Kea flow $(\mathrm{AI}=3)$, which was apparently exposed for $\sim 100 \mathrm{kyr}$ before it was covered by a Mauna Loa flow [Sharp and Renne, 2005].

[49] The Mauna Kea submarine section has higher levels of alteration than the subaerial section (Table 3; Figure 19). For example, massive submarine units have an average AI of 2.9 versus 1.5 for subaerial massive flows, despite both having low vesicularity (Table 3). Hyaloclastites and pillow lavas have slightly greater extents of alteration than the submarine massive units, with average AI values of
3.2 and 3.3 (Table 3), which may result from the more vesicular and porous nature of the hyaloclastites and the fractured character of the pillow lavas, which provide additional reactive surface area. In contrast, the more coherent and nonvesicular intrusions are the least altered rock type within the submarine section (average AI 2.0; Table 3; Figure 19).

[50] Geochemical studies of the HSDP2 core confirm the variable extents of core alteration. Some subaerial and submarine lavas have low $\mathrm{K}_{2} \mathrm{O} / \mathrm{P}_{2} \mathrm{O}_{5}$ $(<1.5)$ and high $\mathrm{Ba} / \mathrm{Rb}$ ratios $(>20)$, reflecting the loss of alkali metals during low-temperature alteration [Huang and Frey, 2003; Rhodes and Vollinger, 2004]. However, fresh glass with magmatic values for $\mathrm{K}_{2} \mathrm{O} / \mathrm{P}_{2} \mathrm{O}_{5}(1.5-2.0)$ is abundant within the submarine section [Stolper et al., 2004]. Preservation of fresh glass and the overall relatively low levels of alteration in the HSDP2 core documented 
here (and by Walton and Schiffman [2003]) are consistent with the low borehole temperatures measured during drilling $\left(8-44^{\circ} \mathrm{C}\right.$; Figure 3$)$ and the relatively young age of the section $(<650$ ka [Sharp and Renne, 2005]).

[51] The HSDP2 section is less altered than the subaerially exposed lavas in the canyons north of Hilo [Frey et al., 1990]. This may reflect both the rapid burial of the HSDP2 section, limiting the effects of near-surface alteration and the cool groundwater temperatures in the HSDP2 section (Figure 2). The greater alteration in the submarine section may reflect the short-term influence of local intrusions and/or the longer-term effects of warm water $\left(30-45^{\circ} \mathrm{C}\right)$ circulating through this zone. However, there is no simple correlation of the location of intrusions and the extent of alteration (e.g., some of the deepest pillow lavas adjacent to intrusions are only weakly altered, although we note that most of these intrusions are $<1 \mathrm{~m}$ thick; Table 3). The level of alteration is also somewhat lower in the upper part of the submarine section where temperatures are lower (Table 3), although the increase in borehole temperature at $\sim 1800 \mathrm{mbsl}$ is not reflected in an increase in the level of alteration (Table 3). This may reflect interplay between the cooler temperatures and greater porosity and permeability in the upper part of the submarine section versus the higher temperatures and lower porosity and permeability in the lower section; alternatively, it could reflect the more recent change in the temperatures within the section.

\section{Comparison to the Kilauea Scientific Observation Hole 1 (SOH1)}

[52] Three deep holes were drilled between 1989 and 1991 along KERZ to assess its geothermal resources. One of these holes, $\mathrm{SOH} 1$, was drilled from an elevation of $\sim 187 \mathrm{~m}$ above sea level to a depth of $1497 \mathrm{mbsl}$ with $88 \%$ recovery of relatively unaltered core [Trusdell et al., 1999; Quane et al., 2000]. Here we compare the near vent, rift zone SOH1 deposits with the distal HSDP2 deposits. We relogged the $\mathrm{SOH} 1$ core using the terminology and methods employed for the HSDP2 core logging and point counted $78 \mathrm{SOH} 1$ thin sections in order to compare results from these two scientific drilling projects in a consistent fashion. The new SOH1 logging (Table S2) resulted in only minor changes in the stratigraphy presented by Quane et al. [2000]. For example, the new compilation places the boundary between the submarine and subaerial sections at the base of the deepest subaerial flows
( 598 mbsl; Table S2). However, overlying this boundary are $\sim 37 \mathrm{~m}$ of subaerial flows capped by a thin carbonate breccia $(0.1 \mathrm{~m}$ thick $)$ and $\sim 10 \mathrm{~m}$ of hyaloclastite (units 238 and 237; Table S2). Quane et al. [2000] chose this uppermost submarine unit as the boundary of the submarine section. Above these two submarine units, the section was emplaced entirely within a subaerial environment. Ages for SOH1 lavas range from 250-500 years for the uppermost flow to $351 \mathrm{ka}$ near the base of the drill hole [Quane et al., 2000; Teanby et al., 2002].

[53] Lava is the dominant rock type within the SOH1 section $(44.5 \%)$, although dikes are also abundant (39.4\%; Table 4). Most dikes have high angle contacts $\left(>60^{\circ}\right)$ with glassy margins and are very weakly vesicular $(<1$ vol. $\%)$. Hyaloclastites are present but less common (13.5\%) and other volcanic fragmental rocks (rubble, ash) and epiclastic deposits (sand, silt and carbonate) together represent a minor component $(2.6 \%$; Table 4$)$. ' $a$ ' $\bar{a}$ flows are the dominant flow type within the subaerial $\mathrm{SOH} 1$ section $(\sim 60 \% ; 120$ out of 220 units; Table 4$)$. Their abundance contrasts with the relative scarcity of ' $\mathrm{a}$ ' $\overline{\mathrm{a}}$ flows on modern K $\mathrm{K}$ lauea ( $\sim 16 \%$ of surface lavas [Holcomb, 1987]), especially along the rift zone axis. In general, the main control on the formation of ' $a$ ' $\bar{a}$ versus pāhoehoe in Hawaiian volcanoes is discharge rate [Rowland and Walker, 1988]. Near-vent Mauna Loa lavas are pāhoehoe, whereas those that flow further from the vent are 'a'ā [e.g., Lockwood and Lipman, 1987]. However, ' $\mathrm{a}^{\prime} \overline{\mathrm{a}}$ flows are more prevalent along the lower KERZ, where the SOH1 core hole is located [Holcomb, 1987]. This higher abundance of ' $a$ ' $\bar{a}$ is thought to be related to the more differentiated composition and cooler temperature of lower rift lavas following prolonged storage in the distal portion of the subaerial rift zone [e.g., Moore, 1983]. Another factor could be the higher volatile contents that are expected in differentiated magmas, which would promote more vigorous lava fountaining and formation of 'a' $\bar{a}$ [e.g., Lockwood and Lipman, 1987; Rowland and Walker, 1990]. Following the approach of Katz and Cashman [2003], the abundance of ' $\mathrm{a}$ ' $\overline{\mathrm{a}}$ within $100 \mathrm{~m}$ intervals of the SOH1 section varies from 56 to $80 \%$, except just above the submarine contact where it drops to $12 \%$ (Table S2). There are also scattered, $10-15 \mathrm{~m}$ thick sequences of thin pāhoehoe flows (mostly $<3 \mathrm{~m}$ thick) throughout the section (Table S2). Although the thicknesses of subaerial pāhoehoe and 'a' $\bar{a}$ flows vary greatly and are similar $(<1$ to $\sim 15 \mathrm{~m})$, average thickness are somewhat greater for ' $a$ ' $\bar{a}$ (3.8 versus 2.2 ; Table 4$)$. 


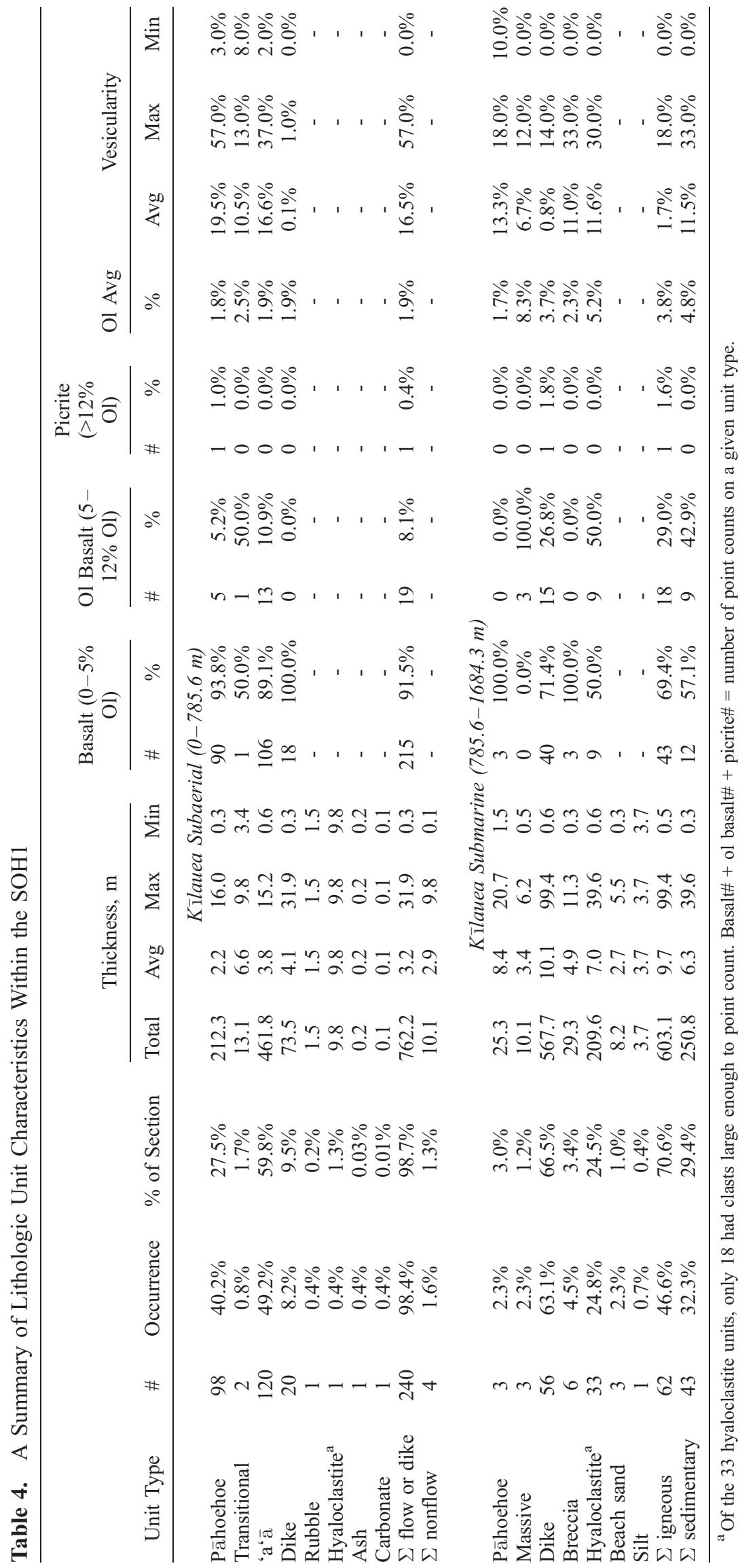


Only two transitional flows are present; their thicknesses are within the ranges of the other flow types (Table 4). The 20 dikes within the subaerial section show a large range in thickness $(0.3-31.9 \mathrm{~m})$. The thicker dikes reflect the low angle intersections of the core hole with these dikes.

[54] The submarine section is dominated by dikes (66.5\%), especially below $1200 \mathrm{~m}$ (Table S2) where they mostly intrude hyaloclastites (Table 4). Without dikes, the submarine section thickness is reduced from 899 to $331 \mathrm{~m}$. The $\mathrm{SOH} 1$ hyaloclastites are similar in appearance to those from the upper part of the HSDP2 submarine section. They are matrix-supported, poorly sorted, weakly to moderately olivine phyric, with abundant, subangular clasts (Table 4). In addition, six lava flows occur within the submarine section. Like the upper part of the HSDP2 section, none are pillow lavas. Three of these lavas have features typical of panhoehoe flows; the others are similar to the massive submarine units encountered in the HSDP2 core and described above in section 5.2.2 (Table S2). Modes based on point counting (100 points) hand specimens indicate that the flows contain 0-11 vol.\% olivine (some with minor amounts of plagioclase) and have $0-18$ vol.\% vesicles (Table S2).

[55] Modes on 58 thin sections (500 points/section) indicate that most $\mathrm{SOH} 1$ rocks $(\sim 85 \%)$ are aphyric to moderately olivine-phyric basalts (i.e., $<1-5$ vol.\% olivine). Only two picritic basalts ( $>12$ vol. $\%$ olivine) were found (a dike at $1100 \mathrm{~m}$ and a pāhoehoe flow at $770 \mathrm{~m}$; Table 5). The subaerial units are only somewhat more vesicular than the submarine deposited lavas (17 versus 13 vol.\%; Table 5). Most SOH1 lavas $(>95 \%)$ contain plagioclase or clinopyroxene microphenocrysts (Table 5). Xenocrysts are much less common in SOH1 rocks than in HSDP2 samples. Only 34\% of the SOH1 rocks contain xenocrysts, whereas $85 \%$ of the HSDP2 lavas do (Tables 3 and 5).

\subsection{Comparison of HSDP2 and SOH1}

[56] A previous study compared lithologic units from a near-vent, rift setting using the $\mathrm{SOH} 4$ core with those from HSDP1 sampled on the flanks of Mauna Loa and Mauna Kea (Figure 1), although only subaerial flow type abundances and thicknesses were compared [Katz and Cashman, 2003]. Here we examine flow types, unit thicknesses, mineralogy, vesicularity, intrusions and level of alteration for both the subaerial and submarine sections of the SOH1 and HSDP2 drillcores. These comparisons allow us to evaluate magmatic and posteruptive processes on Hawaiian volcanoes with applications to other scientific drillcore sections (e.g., IODP).

\subsubsection{Flow Types}

[57] Flow type distribution in drillcores has routinely been used to infer various geologic parameters including distance of the drill site from probable vents. Generally, sections dominated by 'a' $\overline{\mathrm{a}}$ lava are considered distal deposits [e.g., Shipboard Scientific Party, 2002]. This has been shown on Hawaiian volcanoes, for example Mauna Loa, where there is a good correlation of increasing ' $a$ ' $\bar{a}$ abundance with distance from the summit [Lockwood and Lipman, 1987]. Thus it is interesting that the near-vent SOH1 Kîlauea and distal HSDP2 Mauna Kea subaerial sections both have similar and large amounts of ' $a$ ' $\bar{a}(\sim 60 \%$; Tables 1 and 4), whereas the distal HSDP2 Mauna Loa section has only $\sim 37 \%$ ' $\mathrm{a}^{\prime} \bar{a}$. This suggests, as discussed below, that other factors such as lava tube formation, slope, magma temperature and volatile content are also important in determining the dominant flow type.

[58] The dominance of pāhoehoe in the HSDP2 Mauna Loa section probably is related to the formation of lava tubes, which provide insulation allowing lava to be erupted as pāhoehoe long distances from the vent (e.g., the 50-km long flow that almost entered Hilo in 1881 was tube-fed [Lockwood and Lipman, 1987; Trusdell, 1995]). Tube-fed pāhoehoe flows were more common prior to the formation of Mauna Loa's caldera at $\sim 0.75 \mathrm{ka}$, which curtailed overflows from a prehistoric persistent, summit lava lake [Lockwood and Lipman, 1987]. Most of the recent flows that reached the HSDP2 site are ' $\mathrm{a}^{\prime} \overline{\mathrm{a}}$, reflecting a change in eruption style. These younger lavas are from northeast rift zone fountain-fed eruptions, which produced ' $\mathrm{a}$ ' $\overline{\mathrm{a}}$ flows near their vents [Lockwood and Lipman, 1987; Rowland and Walker, 1990].

[59] Another factor influencing the abundance of Mauna Loa pāhoehoe flows may be the location of the HSDP2 drill site on a coastal plain (Figure 1). Lavas deposited on the gentle slopes of Hawaiian coastal plains $\left(\sim 3^{\circ}\right)$ tend to form pāhoehoe lavas [Hon et al., 1994; Lipman and Moore, 1996; Rowland and Garbeil, 2000; Katz and Cashman, 2003]. This observation may also explain the higher abundances of pāhoehoe flows just above the submarine section in both the SOH1 and 


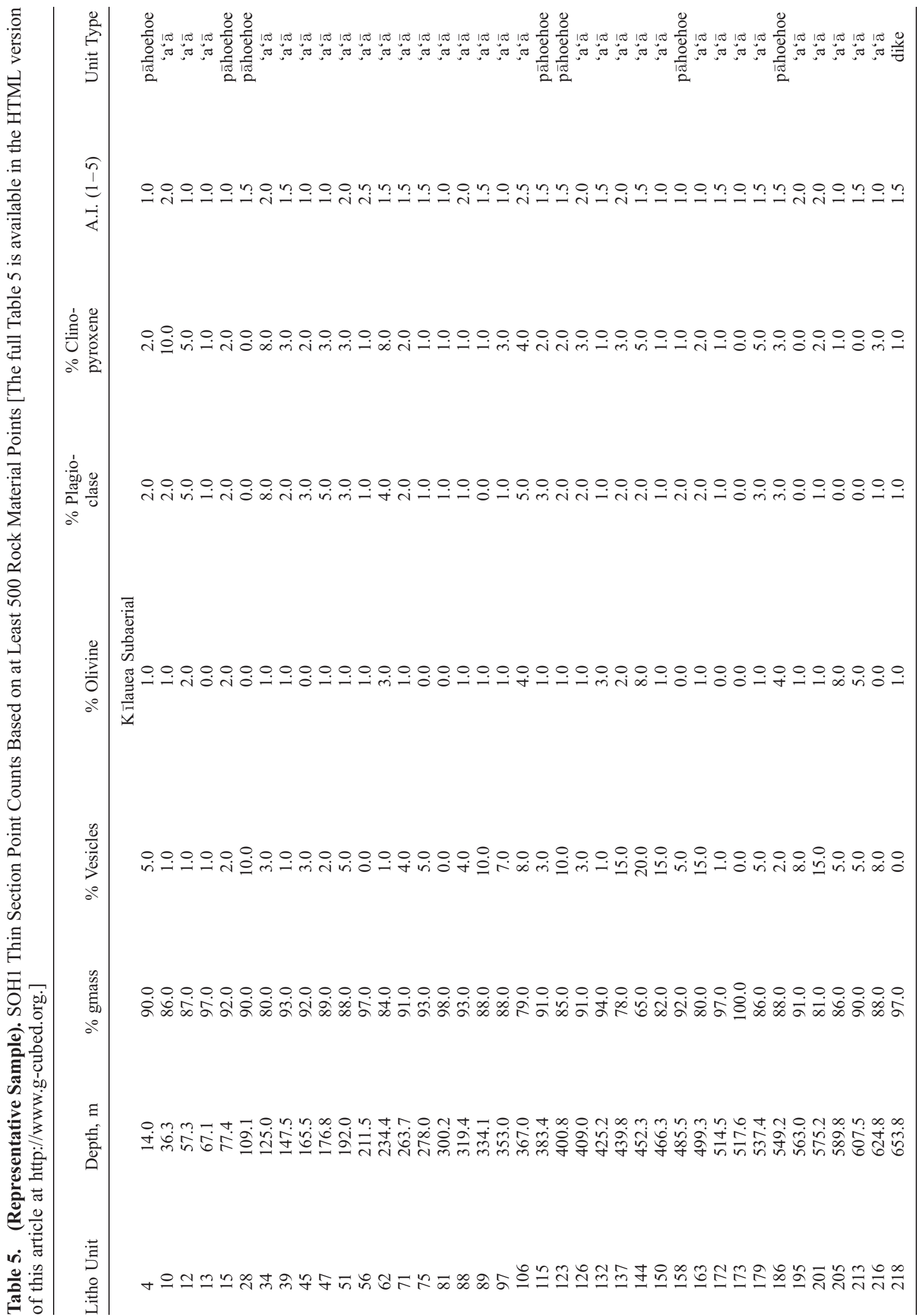


HSDP2 sections $(72 \%$ in the $85-\mathrm{m}$ thick section above the submarine contact in $\mathrm{SOH} 1$ and $57 \%$ in the 150-m thick HSDP2 section above this contact; Tables S1 and S2). Katz and Cashman [2003] also noted this change in flow type proportions just above the submarine contact in the $\mathrm{SOH} 4$ section. Thus there is a clear correlation in the Hawaiian drill core sections for higher abundance of pāhoehoe near the coast, which is an indication that the volcano's slope plays an important role in governing the flow type of its lavas.

[60] The dominance of ' $a$ ' $\bar{a}$ in the subaerial HSDP2 Mauna Kea section may reflect the lack of a well-defined rift zone on that volcano [Yang et al., 1994], which would force flows to travel long distances from summit vents to reach the HSDP2 site (Figure 1). A similar "distance from vent" explanation was offered for the dominance ' $a$ ' $\bar{a}$ in the SOH1 [Katz and Cashman, 2003] on the basis of their analysis of the flow-type data from Quane et al. [2000]. Although SOH1 is along the rift zone, Katz and Cashman [2003] emphasized that eruptions are less frequent along the lower KERZ, so this site may be medial rather than proximal. However, many of the lower KERZ vents as well as those along Mauna Loa rift zone preferentially erupt ' $a$ ' $\bar{a}$ [Holcomb, 1987; Lockwood and Lipman, 1987], so the prevalence of ' $a$ ' $\bar{a}$ cannot a priori be used as evidence of a distant source vent, as noted above regarding eruption style. The dominance of ' $a$ ' $\bar{a}$ along the lower KERZ may instead reflect the abundance of differentiated lavas [Moore, 1983], which erupt at cooler temperatures [ Helz and Thornber, 1987], resulting in higher viscosity [e.g., Swanson, 1973]. Thus differentiated magmas may be more likely to form ' $a$ ' $\bar{a}$ flows. Also, differentiated lavas are likely to be more volatilerich (provided they fractionate at high enough pressures to prevent vapor saturation and loss). Higher volatile contents promote higher fountaining and therefore the formation of 'a' $\bar{a}$ [Lockwood and Lipman, 1987; Rowland and Walker, 1990]. Most SOH1 lavas $(\sim 55 \%)$ are differentiated $(\leq 7 \mathrm{wt} \%$ $\mathrm{MgO})$, whereas nearly all HSDP2 lavas have $>7 \mathrm{wt} \%$ $\mathrm{MgO}$ [Rhodes and Vollinger, 2004]. Thus the extent of fractionation of the lava may play a role in the observed differences in the distributions of flow types in the SOH1 and HSDP2 cores.

\subsubsection{Subaerial Flow Thickness}

[61] There are major differences in the subaerial flow unit thicknesses between the SOH1 and HSDP2 sections (Tables 1 and 4). The average thickness of SOH1 subaerial flows is much less than HSDP2 flows (3.2 m versus 7.0 for Mauna Loa and $7.7 \mathrm{~m}$ for Mauna Kea; Figure 7). The differences are even greater for pāhoehoe lavas $(2.4 \mathrm{~m}$ versus 7.3 for Mauna Loa and 8.5 for Mauna Kea; Figure 7). Distal flows are generally thicker [e.g., Katz and Cashman, 2003], which is consistent with the relatively thick HSDP2 flows, since these flows were deposited at least 37 from the closest vents on the Mauna Loa's northeast rift to $60 \mathrm{~km}$ from its summit, and 14 from closest vents on the Mauna Kea's east rift to $45 \mathrm{~km}$ from its summit (see Figure 1). Another potential factor for flow thickness is slope. Thicker flows are common on gentle slopes, especially pāhoehoe flows, which tend to become inflated [Hon et al., 1994; Lipman and Moore, 1996]. Slopes are also relatively gentle near the SOH1 drill site $\left(3-5^{\circ}\right)$, although these flows tend to be thin (2.4 m average; Table 4) Thus, although slope may play an important role in determining the flow thickness, the threefold increase in the percentage of thicker pāhoehoe flows in the distal Mauna Kea HSDP2 sequences suggests that distance from vent is the dominant factor.

\subsubsection{Mineralogy}

[62] Olivine abundances also differ between the SOH1 and HSDP2 sections (Figure 8). Subaerial $\mathrm{SOH} 1$ lavas are poor in olivine compared to those from the HSDP2 sections (1.4 versus 12.2 and 14.7 vol.\%; Tables 3 and 5), which is consistent with the lower average $\mathrm{MgO}$ content of $\mathrm{SOH} 1$ versus HSDP2 lavas (e.g., $7.8 \mathrm{wt} \%$ versus $14.6 \mathrm{wt} \%$ for HSDP2 Mauna Loa lavas). The low olivine contents in the SOH1 section are probably related to the location of the drill site on the distal portion of Kìlauea's east rift zone where eruptions are less frequent than nearer the summit. Less frequent eruptions reflects the lower magma fluxes to the lower rift and longer period of magma storage between eruptions, which leads to the formation of more fractionated lavas [e.g., Wright and Fiske, 1971; Moore, 1983]. The presence of clinopyroxene and plagioclase ph or mph in almost all of the SOH1 flows (Table 5) is an indication that they are differentiated [e.g., Wright and Fiske, 1971]. However, these minerals commonly show resorption and/or complex zoning and the rocks have $>7 \mathrm{wt} \% \mathrm{MgO}$. Thus, like HSDP2 rocks, the presence of clinopyroxene and plagioclase in some $\mathrm{SOH} 1$ rocks probably reflects magma mixing involving a differentiated magma.

\subsubsection{Vesicularity}

[63] ' $A$ ' $\bar{a}$ lavas show the greatest differences in vesicularity between the SOH1 and HSDP cores 
(16.6 versus 6.7 and 8.2 vol.\% for Mauna Loa and Mauna Kea flows; Tables 1 and 4, Figure 9). This flow type distinction was also noted above for olivine content. ' $A$ ' $\bar{a}$ has lower vesicularity than pāhoehoe for all three volcanoes, which has been observed in previous studies of Hawaiian lavas [e.g., Rowland and Walker, 1990]. The vesicularities of pāhoehoe from the SOH1 and Mauna Kea section are similar (19.5 vol.\% for SOH1 versus 20.8 vol.\% for HSDP2 Mauna Kea), whereas Mauna Loa pāhoehoe have much lower vesicularities (13.7 vol.\%). The less common transitional lavas are nearly identical in vesicularity at $11 \pm$ 1 vol.\% for all three volcanoes (Tables 1 and 4), although the olivine contents in these lavas are distinct (2 vol.\% for SOH1 versus 10 vol.\% for Mauna Loa). A decrease in vesicularity is generally expected with distance from the vent [Walker, 1989], which is consistent with the lower vesicularity of the Mauna Loa pāhoehoe lavas and the lower vesicularity of the HSDP2 ' $a$ ' $\bar{a}$ flows. However, it does not explain the similarities in vesicularity of the pâhoehoe from the SOH1 and Mauna Kea sections of the HSDP2 core or the transitional lavas from all three volcanoes. We currently have no explanation for these observations.

\subsubsection{Submarine Massive Flows}

[64] Submarine massive flows, a flow type seldom described for submarine lavas [Walker, 1992], occur in both the SOH1 and HSDP2 sections (see section 5.2.2). These mostly thin flows $(\sim 3 \mathrm{~m}$ in both sections) are not associated with pillow lavas and are much less common $(\sim 7 \%)$ than the hyaloclastites with which they are interbedded (Tables 1 and 4). The presence of massive flows in both drill cores indicates that conditions required for their deposition (i.e., avoiding explosive interaction with seawater) are independent of flow distance traveled. Recent studies of magma/water interaction indicate that the geometry of the interaction and amount of wave action are important factors controlling explosive versus nonexplosive behavior of Hawaiian lavas as they enter the ocean [e.g., Tribble, 1991]. As stated above, the origin and significance of the submarine massive flows are unknown.

\subsubsection{Hyaloclastites}

[65] The hyaloclastite units are abundant in the shallow submarine sections of HSDP2 and SOH1 core holes $(82 \%$ and $23 \% ; 73 \%$ if the dikes in SOH1 are excluded; Tables 1 and 4) and are similar lithologically (Tables S1 and S2). However, the
SOH1 units are somewhat thinner (7 versus $11 \mathrm{~m}$; Tables 1 and 4; Figure 10) and the clasts are more vesicular (12 versus 3 vol.\%; Tables 3 and 4). The thinness of the SOH1 units is, however, mostly a consequence of crosscutting dikes (Table S2), limiting the assigned thicknesses of hyaloclastite units, which as described above is difficult and somewhat subjective. The higher vesicularity of lithic clasts in SOH1 hyaloclastites is probably related to closer proximity to source vents. The abundance of hyaloclastites in both drill core sections confirm that this rock type is an important component of the shallow submarine sections of Hawaiian volcanoes, as was anticipated by Moore and Fiske [1969]. However, the abundance of hyaloclastites in the HSDP2 core drops dramatically to $36.2 \%$ in the lower submarine zone (Table 1 ) and to $0 \%$ below $2920 \mathrm{mbsl}$. None have been encountered in the 2005 HSDP2 drilling to $3.3 \mathrm{~km}$. Thus the suggestion of Moore and Chadwick [1995] that the bulk of Hawaiian volcanoes are composed of fragmental debris seems in question. Rather, these volcanoes probably consist of a pedestal of pillow lavas $>5 \mathrm{~km}$ thick, draped by a veneer $\sim 1 \mathrm{~km}$ thick of dominantly fragmental debris on its upper flanks (Figure 20), as originally proposed by Moore and Fiske [1969] and reaffirmed by submersible observations [Fornari et al., 1979; Garcia and Davis, 2001]. This wedge of fragmental material grows largely by slumping of nearshore, water-quenched fragments of subaerially erupted lavas. The wedge advances away from the shoreline much like a prograding delta. Continued HSDP drilling should help to evaluate this model.

\subsubsection{Intrusions}

[66] Unlike the HSDP2 section, dikes are the dominant lithology in the SOH1 section, composing $41 \%$ of the entire section and $72 \%$ of the submarine section (Figure 6). The average SOH1 intrusion thickness is much greater than in the HSDP2 section (10 versus $4 \mathrm{~m}$ ) and than reported values for dikes in Hawaiian rift zones $(\sim 0.7 \mathrm{~m}$ [Walker, 1987]). The contacts of the SOH1 dikes are high angle $\left(70-90^{\circ}\right)$, which probably contributes to the significant thickness of many of these units in the drillcore (up to $99.4 \mathrm{~m}$; Table 4). In contrast, most HSDP2 intrusions are thin and subhorizontal (Table S1). The greater abundance of dikes in the SOH1 section likely also contributes to the more altered nature of rocks in the SOH1 section (Figure 19). Indeed, hydrothermal alteration in Hawaiian rift zones can be profound, as evidenced 


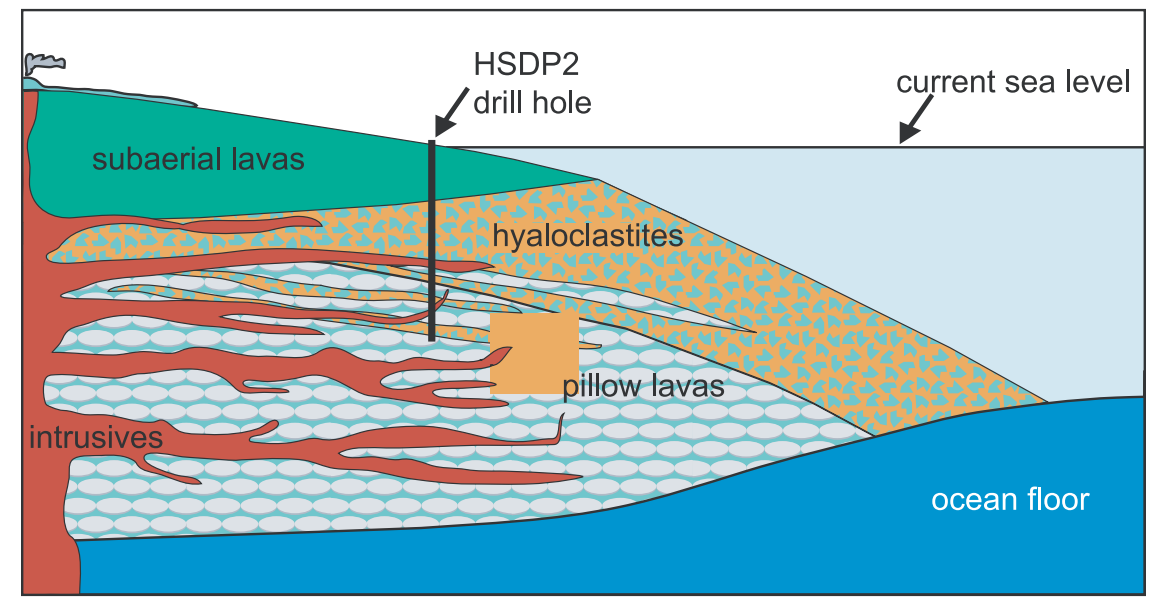

Figure 20. Schematic cross section for the internal structure of Mauna Kea volcano near the end of the subaerial shield stage based on results from HSDP2 drilling and submersible observations of Mauna Loa and Loihi volcanoes [Garcia and Davis, 2001; Garcia et al., 2006]. See text for discussion of figure.

by temperatures of $306^{\circ} \mathrm{C}$ in $\mathrm{SOH} 4$ and $206^{\circ} \mathrm{C}$ in SOH1 [Bargar et al., 1995]. It was primarily for this reason that the HSDP2 was chosen to be distant from known rift zones (Figure 1).

\section{Implications for Hawaiian Volcano Growth}

[67] The HSDP2 program has provided the deepest probe yet into a Hawaiian volcano. The core presents the first opportunity for a detailed examination of the submarine growth on the upper flanks of Mauna Kea volcano. The HSDP2 stratigraphic sequence can be interpreted in the content of a volcano's evolution using a basic temporal model for Hawaiian volcanoes [e.g., Garcia et al., 2006] and a schematic cross section (Figure 20).

[68] The basement for Mauna Kea has two basic components: (1) a 5-6 km thick section of Cretaceous oceanic crust overlain by $\sim 200 \mathrm{~m}$ thick of pelagic sediments and detrital debris from the older Hawaiian islands [Waggoner, 1993; Leslie et al., 2002] and (2) the flanks of Kohala, the adjacent older Hawaiian volcano [DePaolo and Stolper, 1996; Baker et al., 2003]. Assuming typical Hawaiian volcanoes form in $\sim 1.5$ my [Garcia et al., 2006], the early history of Mauna Kea (1-1.5 Ma) was not recovered and is unlikely to be sampled at the HSDP2 site given its significant distance $(\sim 45 \mathrm{~km})$ from the volcano's summit. For example, the strongly elongate rift zones on Loihi, the youngest Hawaiian volcano, extend only $\sim 10 \mathrm{~km}$ to the north and $20 \mathrm{~km}$ to the south of its summit, although it has been growing for $\sim 0.4$ m.y. and formed a five $\mathrm{km}$ tall edifice [Garcia et al., 2006]. On the basis of submersible observations of Loihi seamount, the only Hawaiian volcano where this preshield stage is well preserved and exposed [Garcia et al., 2006], Mauna Kea's early growth probably was dominated by intrusion of dikes and extrusion of pillow lavas (Figure 20). During the next few 100,000 years, the summit of Mauna Kea is likely to have breached sea level and started shield-stage growth. This probably occurred before the HSDP2 core was deposited on basis of modeling the volcanoes growth [Baker et al., 2003] and the presence of degassed glasses in the lower submarine hyaloclastites [Seaman et al., 2004]. Growth by pillow lava extrusion and dike intrusion continued for the next $350 \mathrm{kyr}$ on the submarine flanks of this volcano (Figure 20). This interpretation is based on studies of the dissected southwestern submarine flank of neighboring Mauna Loa, which consists almost entirely of pillow lavas [Garcia et al., 1995; Garcia and Davis, 2001] and the surface features of the submarine east rift zone of Killauea [e.g., Smith et al., 2002].

[69] At $\sim 650 \pm 50 \mathrm{ka}$, the age of the base of section at $\sim 3,100$ mbsl [Sharp and Renne, 2005], the HSDP2 site was $\sim 1350 \pm 135 \mathrm{mbsl}$, on the basis of an assumed subsidence rate of $2.7 \mathrm{~mm} / \mathrm{yr}$ (Bridges et al., submitted manuscript, 2007). Continued submarine growth of subaerial Mauna Kea volcano was dominated by pillow lava derived from vents $>500 \mathrm{mbsl}$ based on the presence of undegassed pillow rim glasses. Pillow lavas continued as the dominant rock type with increasing amounts of fragmental volcanic debris upsection 
for another $\sim 1 \mathrm{~km}$. The hyaloclastite debris was derived from distant degassed lavas quenched while erupting into the ocean and minor local fragmentation of undegassed pillow lavas (Bridges et al., submitted manuscript, 2007). By 520 \pm $50 \mathrm{ka}$, pillow deposition stopped at the drill site and fragmental volcanic debris dominated the section. The drill site was now $\sim 600 \pm 135 \mathrm{mbsl}$. Glasses from both the fragmental debris and interbedded massive pillow lavas are nearly all degassed [Seaman et al., 2004], suggesting that both rock types were subaerially erupted [Davis et al., 2003]. The emergence of the HSDP2 drill site above sea level at $\sim 415 \pm 50 \mathrm{ka}$ [Sharp and Renne, 2005] was abrupt as a $\sim 16 \mathrm{~m}$ thick eruptive sequence converted the site to a subaerial environment. The HSDP2 site remained subaerial for the rest of the growth of Mauna Kea ( 200 kyr) with deposition of $834 \mathrm{~m}$ of lava flows and infrequent ash deposits. The upper $\sim 95 \mathrm{~m}$ of this sequence consists of postshield lavas, which were deposited over a period $\sim 100 \mathrm{kyr}$. The last Mauna Kea lava covered the HSDP2 site at $\sim 200 \mathrm{ka}$. The site remain exposed for $\sim 100 \mathrm{kyr}$ as Mauna Kea continued to erupt elsewhere, as recently as $\sim 4 \mathrm{ka}$ [Wolfe et al., 1997] with decreasing frequency, especially during its hawaiitic substage of postshield volcanism starting $65 \mathrm{ka}$ [Frey et al., 1990]. To the south, Mauna Loa volcano was continuing to grow, vigorously overlapping Mauna Kea. Finally, at $\sim 100 \mathrm{ka}$, Mauna Loa lavas found their way to the HSDP2 site in the valley between the Hilo Ridge and Kilauea east rift and created a $\sim 250 \mathrm{~m}$ thick section. The last flow covered the HSDP 2 and HSDP1 sites $\sim 1,340$ years ago [Beeson et al., 1996].

[70] In summary, the first half of Mauna Kea's history has yet to be revealed at the HSDP2 site. Results from HSDP2 suggest that the lower flanks of the volcano may consist primarily of pillow lava deposited during the submarine growth of subaerial Mauna Kea. Fragmental volcanic debris becomes a dominant component on the distal flanks of this volcano only as the section shoaled (to depths of $\sim 650 \mathrm{mbsl}$ at the HSDP2 site). The rise of Mauna Kea above sea level at the HSDP2 site was rapid and irreversible, although the HSDP1 site bobbed above and below sea level [Beeson et al., 1996]. Lava deposition decreased markedly from 300 to $200 \mathrm{ka}$ as the volcano entered the postshield stage. Although Mauna Kea has continued to erupt, only Mauna Loa lavas have reached the HSDP2 site in the last $100 \mathrm{ka}$. Another Mauna Loa flow will almost certainly reach the site, although with the lengthy period between successive flows at the site, $\sim 3,000 \mathrm{y}$, it may be a long time before the next flow arrives.

\section{Conclusions}

[71] The Hawai'i Scientific Drilling Project provided the first opportunity to peer into the deep interior of a Hawaiian shield volcano. Phase 2 of the project drilled $3.1 \mathrm{~km}$ into the island of Hawai' $\mathrm{i}$ at a site near the city of Hilo. Drilling at this site first encountered $1,079 \mathrm{~m}$ of subaerially erupted lava with minor interbedded ash, sand and soil. The upper $247 \mathrm{~m}$ of this section are from Mauna Loa with roughly equal amounts of pāhoehoe and ' $a$ ' $\bar{a}$ lavas, like the volcano's current surface, which were deposited on a coastal plain. An $\sim 100 \mathrm{kyr}$ unconformity separates these lavas from am underlying $832 \mathrm{~m}$ thick section of Mauna Kea subaerial lavas deposited from 200 to $400 \mathrm{ka}$ during the postshield stage and the waning shield stages of volcanism. Most of these flows are ' $a$ ' $\bar{a}$, which may reflect deposition of distal flows on relatively steep slopes. The submarine section starts abruptly with one eruptive sequence spanning the transition. Beneath this transition, all of the volcanic and sedimentary units were deposited in a submarine environment. The submarine Mauna Kea section contains an upper, $905 \mathrm{~m}$ thick, hyaloclastite-rich zone and a lower, 2,114 $\mathrm{m}$ thick pillow lava dominated zone. Pillow lavas are absent in the upper submarine section. Hyaloclastite abundance decreases rapidly down section, contrary to a recent model for the structure of Hawaiian volcanoes. The HSDP2 results support a model that Hawaiian volcanoes are built on a pedestal of pillow lavas ( $>5 \mathrm{~km}$ thick) capped by a relatively thin veneer ( $\sim 1 \mathrm{~km}$ thick at the location of the HSDP2 drill site) of rapidly quenched, fragmented lava debris. These fragmental rocks are overlain by a section consisting of only subaerial lavas, reflecting Mauna Kea's rapid growth during its shield stage.

[72] The HSDP2 section has both similarities to and differences from core recovered from the $1.7 \mathrm{~km}$ deep SOH1 well drilled along Kīlauea's lower east rift zone. Pāhoehoe flows from both holes have similarly lower olivine contents and higher vesicularity than interbedded ' $a$ ' $\bar{a}$ flows. However, the HSDP2 ' $a$ ' $\bar{a}$ flows have higher olivine contents and lower vesicularity than interlayered pāhoehoe flows. The differences between ' $a$ ' $\bar{a}$ flows in the two drill cores may reflect the greater distance to vent for HSDP2 compared to the SOH1 section rather than magmatic differences. Numerous high angle dikes cut the $\mathrm{SOH} 1$ hole, reflecting its loca- 
tion in Kîlauea's east rift zone. The abundant dikes and the overall higher temperatures in the $\mathrm{SOH} 1$ hole caused more alteration in this section than observed in the older HSDP2 section. Thus the selection of the HSDP2 site distant from any known rift zone was a successful strategy in minimizing alteration to the core and recovering the freshest possible rock for geochemical analyses.

\section{Acknowledgments}

[73] The HSDP2 drilling project was an enormous collaborative effort involving many people, including principal investigators D. DePaolo, E. Stolper, and D. Thomas, the drilling engineer Bruce Howell, the head driller Ron Fierbach, and numerous drilling helpers who carefully extruded the core. The core was logged by a remarkable team led by Angie Roach and Caroline Seaman. Thanks also to Jenny Riker for the Mauna Loa thin section modes, to Scott Rowland for constructive comments on an early draft of this paper, and to J. M. Rhodes and D. Geist for journal reviews. This work was supported by NSF grants EAR03-36874 (M. Garcia), EAR9528534 (Don Thomas), and EAR-9528594 (E. Stolper) and the International Continental Drilling Program. The paper is SOEST contribution 7000 and Caltech Division of Geological and Planetary Sciences contribution 9170.

\section{References}

Baker, M. B., S. Alves, and E. M. Stolper (1996), Petrography and petrology of the HSDP lavas: Inferences from olivine phenocryst abundances and compositions, J. Geophys. Res., 101, 11,715-11,728.

Baker, M. B., D. A. Stolper, E. M. Stolper, and Y. Fialko (2003), Modeling the growth of Hawaiian volcanoes, Eos Trans. $A G U, 84(46)$, abstract V11B-03.

Bargar, K. E., T. Keith, and F. A. Trusdell (1995), Fluid inclusion evidence for past temperature fluctuations in the Kilauea east rift zone geothermal area, Hawaii, Geothermics, 24, $639-659$.

Beeson, M. H., D. A. Clague, and J. P. Lockwood (1996), Origin and depositional environment of clastic deposits in the Hilo drill hole, Hawaii, J. Geophys. Res., 101, 11,61711,629 .

Blichert-Toft, J., D. Weis, C. Maerschalk, A. Agranier, and F. Albarède (2003), Hawaiian hot spot dynamics as inferred from the $\mathrm{Hf}$ and $\mathrm{Pb}$ isotope evolution of Mauna Kea volcano, Geochem. Geophys. Geosyst., 4(2), 8704, doi:10.1029/ 2002 GC000340.

Buchanan-Banks, J. M., and J. P. Lockwood (1982), Geological map of the Alenaio-Waipahoehoe steams area, South Hilo, Hawaii, U.S. Geol. Surv. Open File Rep., 82-655.

Compton, R. R. (1962), Manual of Field Geology, 378 pp., John Wiley, Hoboken, N. J.

Davis, M. G., M. O. Garcia, and P. Wallace (2003), Volatiles in glasses from Mauna Loa volcano, Hawai'i: Implications for magma degassing and contamination, and growth of Hawaiian volcanoes, Cont. Mineral. Petrol., 144, 570-591.

DePaolo, D. J., and E. M. Stolper (1996), Models of Hawaiian volcano growth and plume structure: Implications of results from the Hawaii Scientific Drilling Project, J. Geophys. Res., $101,11,643-11,654$.
DePaolo, D. J., E. Stolper, and D. Thomas (1996), The Hawaii Scientific Drilling Project: Summary of preliminary results, GSA Today, 6, 1-8.

DePaolo, D., E. Stolper, and D. Thomas (2001), Deep drilling into a Hawaiian volcano, Eos Trans. $A G U, 82,149$.

Fornari, D. J., A. Malahoff, and B. C. Heezen (1979), Submarine slope micromorphology and volcanic substructure of the Island of Hawaii inferred from visual observations made from U.S. Navy Deep Submergence Vehicle (DSV) SEA CLIFF, Mar. Geol., 32, 1-20.

Frey, F. A., W. S. Wise, M. O. Garcia, H. West, S. T. Kwon, and A. Kennedy (1990), Evolution of Mauna Kea Volcano, Hawaii: Petrologic and geochemical constraints on postshield volcanism, J. Geophys. Res., 95, 1271-1300.

Frey, F. A., M. O. Garcia, W. S. Wise, A. Kennedy, P. Gurriet, and F. Albarède (1991), The evolution of Mauna Kea volcano, Hawaii: Petrogenesis of tholeiitic and alkalic basalts, J. Geophys. Res., 96, 14,347-14,375.

Garcia, M. O. (1996), Petrography and olivine and glass chemistry of lavas from the Hawaii Scientific Drilling Project, J. Geophys. Res., 101, 11,701-11,713.

Garcia, M. O. (2002), Submarine picritic basalts from Koolau volcano, Hawaii: Implications for parental magma compositions and mantle source, in Hawaiian Volcanoes: Deep Underwater Perspectives, Geophys. Monogr. Ser., vol. 128, edited by E. Takahashi et al., pp. 391-402, AGU, Washington, D. C.

Garcia, M. O., and M. G. Davis (2001), Submarine growth and internal structure of ocean island volcanoes based on submarine observations of Mauna Loa volcano, Hawaii, Geology, 29, 163-166.

Garcia, M. O., D. Muenow, K. E. Aggrey, and J. R. O'Neil (1989), Major element, volatile, and stable isotopic geochemistry of Hawaiian submarine tholeiitic glasses, J. Geophys. Res., 94, 10,525-10,538.

Garcia, M. O., T. P. Hulsebosch, and J. M. Rhodes (1995), Olivine-rich submarine basalts from the southwest rift zone of Mauna Loa volcano: Implications for magmatic processes and geochemical evolution, in Mauna Loa Revealed: Structure, Composition, History, and Hazards, Geophys. Monogr. Ser, vol. 92, edited by J. M. Rhodes and J. P. Lockwood, pp. 219-239, AGU, Washington, D. C.

Garcia, M. O., A. J. Pietruszka, and J. M. Rhodes (2003), A petrologic perspective of the summit magma chamber of Kīlauea Volcano, Hawai'i, J. Petrol., 44, 2313-2339.

Garcia, M. O., J. Caplan-Auerbach, E. H. De Carlo, M. D. Kurz, and N. Becker (2006), Geology, geochemistry and earthquake history of Loihi seamount, Hawaii's youngest volcano, Chem. Erde, 66, 81-108.

Hawaii Scientific Drilling Project (2000), Core Logs and Summarizing Data, edited by C. Seaman, M. O. Garcia, and E. Stolper, Calif. Inst. of Technol., Pasadena, Calif.

Helz, R. T. (1987), Diverse olivine types in lava of the 1959 eruption of Kilauea volcano and their bearing on eruption dynamics, in Volcanism in Hawaii, edited by R. W. Decker, T. L. Wright, and P. H. Stauffer, U.S. Geol. Surv. Prof. Pap., 1350(1), 691-722.

Helz, R. T., and C. R. Thornber (1987), Geothermometry of Kilauea Iki lava lake, Bull. Volcanol., 49, 651-658.

Hill, D. P., and J. J. Zucca (1987), Geophysical constraints on the structure of Kilauea and Mauna Loa volcanoes and some implications for seismomagmatic processes, U.S. Geol. Surv. Prof. Pap., 1350, 903-917.

Holcomb, R. T. (1987), Volcanism in Hawaii: Eruptive history and long-term behavior of Kilauea volcano, U.S. Geol. Surv. Prof. Pap., 1350, 261-350. 
Hon, K., J. Kauahikaua, R. Denlinger, and K. Mackay (1994), Emplacement and inflation of pahoehoe sheet flows: Observations and measurements of active lava flows on Kilauea Volcano, Hawaii, Geol. Soc. Am. Bull., 106, 351-370.

Huang, S., and F. A. Frey (2003), Trace element abundances of Mauna Kea basalt from phase 2 of the Hawaii Scientific Drilling Project: Petrogenetic implications of correlations with major element content and isotopic ratios, Geochem. Geophys. Geosyst., 4(6), 8711, doi:10.1029/2002GC000322.

Katz, M. G., and K. V. Cashman (2003), Hawaiian lava flows in the third dimension: Identification and interpretation of pahoehoe and 'a'a distribution in the KP-1 and SOH-4 cores, Geochem. Geophys. Geosyst., 4(2), 8705, doi:10.1029/ 2001GC000209.

Leslie, S. C., G. F. Moore, J. K. Morgan, and D. J. Hills (2002), Seismic stratigraphy of the frontal Hawaiian moat: Implications for sedimentary processes at the leading edge of an oceanic hotspot trace, Mar. Geol., 184, 143162.

Lipman, P. W. (1995), Declining growth of Mauna Loa during the last 100,000 years: Rates of lava accumulation vs. gravitational subsidence, in Mauna Loa Revealed: Structure, Composition, History, and Hazards, Geophys. Monogr. Ser., vol. 92, edited by J. M. Rhodes and J. P. Lockwood, pp. 45-80, AGU, Washington, D. C.

Lipman, P. W., and J. G. Moore (1996), Mauna Loa lava accumulation rates at the Hilo drill site: Formation of lava deltas during a period of declining overall volcanic growth, J. Geophys. Res., 101, 11,631-11,642.

Lockwood, J. P., and P. W. Lipman (1987), Holocene eruptive history of Mauna Loa Volcano, U.S. Geol. Surv. Prof. Pap., 1350, 509-536.

Macdonald, G. A. (1949), Petrography of the island of Hawaii, U.S. Geol. Surv. Prof. Pap., 214-D, 1-96.

Moore, J. G. (2001), Density of basalt core from Hilo drill core, Hawaii, J. Volcanol. Geotherm. Res., 112, 221-230.

Moore, J. G., and W. W. Chadwick, Jr. (1995), Offshore geology of Mauna Loa and adjacent areas, Hawaii, in Mauna Loa Revealed: Structure, Composition, History, and Hazards, Geophys. Monogr. Ser., vol. 92, edited by J. M. Rhodes and J. P. Lockwood, pp. 21-44, AGU, Washington, D. C.

Moore, J. G., and R. S. Fiske (1969), Volcanic substructure inferred from dredge samples and ocean-bottom photographs, Hawaii, Geol. Soc. Am. Bull., 80, 1191-1201.

Moore, J. G., R. L. Phillips, R. W. Grigg, D. W. Peterson, and D. A. Swanson (1973), Flow of lava into the sea, 19691971, Kilauea volcano, Hawaii, Geol. Soc. Am. Bull., 84, $537-546$

Moore, J. G., B. L. Ingram, K. R. Ludwig, and D. A. Clague (1996), Coral ages and island subsidence, Hilo drill hole, J. Geophys. Res., 101, 11,599-11,606.

Moore, R. G. (1983), Distribution of differentiated tholeiitic basalts on the lower east rift zone of Kilauea Volcano, Hawaii: A possible guide to geothermal exploration, Geology, 11, 136-140.

Quane, S. L., M. O. Garcia, H. Guillou, and T. P. Hulsebosch (2000), Magmatic history of the East Rift Zone of Kilauea Volcano, Hawaii based on drill core from $\mathrm{SOH} 1, \mathrm{~J}$. Volcanol. Geotherm. Res., 102, 319-338.

Rhodes, J. M. (1996), Geochemical stratigraphy of lava flows sampled by the Hawaii Scientific Drilling Project, J. Geophys. Res., 101, 11,729-11,746.

Rhodes, J. M., and M. J. Vollinger (2004), Composition of basaltic lavas sampled by phase-2 of the Hawaii Scientific Drilling Project: Geochemical stratigraphy and magma types,
Geochem. Geophys. Geosyst., 5, Q03G13, doi:10.1029/ $2002 \mathrm{GC} 000434$.

Rowland, S. K., and H. Garbeil (2000), Slopes of oceanic volcanoes, in Remote Sensing of Active Volcanism, Geophys. Monogr. Ser, vol. 116, edited by P. Mouginis-Mark, J. Crisp, and J. Fink, pp. 223-247, AGU, Washington, D. C.

Rowland, S. K., and G. P. L. Walker (1988), Mafic-crystal distributions, viscosities and lava structures of some Hawaiian lava flows, J. Volcanol. Geotherm Res., 35, 55-66.

Rowland, S. K., and G. P. L. Walker (1990), Pahoehoe and aa in Hawaii: Volumetric flow rate controls the lava structure, Bull. Volcanol., 52, 615-628.

Ryan, M. P. (1988), The mechanics and three-dimensional internal structure of active magmatic systems: Kilauea Volcano, Hawaii, J. Geophys. Res., 93, 4213-4248.

Seaman, C., S. B. Sherman, M. O. Garcia, M. B. Baker, B. Balta, and E. Stolper (2004), Volatiles in glasses from the HSDP2 drill core, Geochem. Geophys. Geosyst., 5, Q09G16, doi:10.1029/2003GC000596.

Sharp, W. D., and P. R. Renne (2005), The ${ }^{40} \mathrm{Ar} /{ }^{39} \mathrm{Ar}$ dating of core recovered by the Hawaii Scientific Drilling Project (phase 2), Hilo, Hawaii, Geochem. Geophys. Geosyst., 6, Q04G17, doi:10.1029/2004GC000846.

Shipboard Scientific Party (2002), Leg 197 summary, Proc. Ocean Drill. Program Initial Rep., 197, 1-92.

Smith, D. K., L. S. L. Kong, K. T. M. Johnson, and J. R. Reynolds (2002), Volcanic morphology of the submarine Puna Ridge, Kilauea volcano, in Hawaiian Volcanoes: Deep Underwater Perspectives, Geophys. Monogr. Ser., vol. 128, edited by E. Takahashi et al., pp. 125-142, AGU, Washington, D. C.

Stolper, E., S. Sherman, M. Garcia, M. Baker, and C. Seaman (2004), Glass in the submarine section of the HSDP2 drill core, Hilo, Hawaii, Geochem. Geophys. Geosyst., 5, Q07G15, doi:10.1029/2003GC000553.

Streckeisen, A. L. (1973), Classification and nomenclature of volcanic rocks, Geology, 7, 331-335.

Swanson, D. (1973), Pahoehoe flows from the 1969-1971 Mauna Ulu eruption, Kilauea volcano, Hawaii, Geol. Soc. Am. Bull., 84, 615-626.

Teanby, N., C. Laj, D. Gubbins, and M. Pringle (2002), A detailed palaeointensity and inclination record from drill core SOH1 on Hawaii, Phys. Earth Planet. Inter., 131, 101-140.

Thomas, D. M., F. Paillet, and M. Conrad (1996), Hydrogeology of the Hawaii Scientific Drilling Project borehole KP-1: Groundwater geochemistry and regional flow patterns, J. Geophys. Res., 101, 11,683-11,694.

Tilling, R. I., and J. J. Dvorak (1993), Anatomy of a basaltic volcano, Nature, 363, 125-133.

Tribble, G. (1991), Underwater observations of active lava flows from Kilauea volcano, Hawaii, Geology, 19, 633-636.

Trusdell, F. A. (1995), Lava flow hazards and risk assessment on Mauna Loa volcano, Hawaii, in Mauna Loa Revealed: Structure, Composition, History, and Hazards, Geophys. Monogr. Ser., vol. 92, edited by J. M. Rhodes and J. P. Lockwood, pp. 327-336, AGU, Washington, D. C.

Trusdell, F. A., E. Novak, S. R. Evans, and K. Okano (1999), Core lithology from the state of Hawaii Scientific Observation Hole 1, Kilauea volcano, Hawaii, U.S. Geol. Surv. Open File Rep., 99-389.

Waggoner, D. G. (1993), The age and alteration of central Pacific oceanic crust near Hawaii, Site 843, Proc. Ocean Drill. Program Sci. Results, 136, 119-132.

Walker, G. P. L. (1987), The dike complex of the Koolau volcano, Oahu: Internal structure of a Hawaiian rift zone, U.S. Geol. Surv. Prof. Pap., 1350, 961-993. 
Walker, G. P. L. (1989), Spongy pahoehoe in Hawaii: A study of vesicle-distribution patterns in basalt and their significance, Bull. Volcanol., 51, 199-209.

Walker, G. P. L. (1992), Morphometric study of pillow-size spectrum among pillow lavas, Bull. Volcanol., 54, 459474.

Walton, A. W., and P. Schiffman (2003), Alteration of hyaloclastites in the HSDP 2 Phase 1 Drill Core 1. Description and paragenesis, Geochem. Geophys. Geosyst., 4(5), 8709, doi:10.1029/2002GC000368.

Wanless, V. D., M. O. Garcia, F. A. Trusdell, J. M. Rhodes, M. D. Norman, D. Weis, D. J. Fornari, M. D. Kurz, and H. Guillou (2006), Submarine radial vents on Mauna Loa Volcano, Hawai'i, Geochem. Geophys. Geosyst., 7, Q05001, doi:10.1029/2005GC001086.
Wentworth, C. K., and G. A. Macdonald (1953), Structures and forms of basaltic rocks in Hawaii, U.S. Geol. Surv. Bull., 994, $98 \mathrm{pp}$.

Wilkinson, J. F. G., and H. D. Hensel (1988), The petrology of some picrites from Mauna Loa and Kilauea volcanoes, Hawaii, Contrib. Mineral. Petrol., 98, 326-345.

Wolfe, E. W., W. S. Wise, and G. B. Dalrymple (1997), Geology and petrology of Mauna Kea volcano, Hawaii: A study of postshield volcanism, U.S. Geol. Surv. Prof. Pap., 1557.

Wright, T. L., and R. S. Fiske (1971), Origin of the differentiated and hybrid lavas of Kilauea Volcano, Hawaii, J. Petrol., 12, $1-65$.

Yang, H.-J., F. A. Frey, M. O. Garcia, and D. A. Clague (1994), Submarine lavas from Mauna Kea volcano, Hawaii: Implications for Hawaiian shield-stage processes, J. Geophys. Res., 99, 15,577-15,594. 